\title{
OS DIREITOS DA PERSONALIDADE NO CÓDIGO CIVIL BRASILEIRO
}

\section{PERSONALITY RIGHTS IN THE BRAZILIAN CIVIL CODE}

\section{GILBERTO HADDAD JABUR}

Mestre e Doutor em Direito pela PUCSP. Professor de Direito Civil na PUCSP. Presidente da Cátedra da Família da PUCSP. Membro do Conselho Científico da Associação de Direito de Família e das Sucessões - ADFAS. Membro da Academia Iberoamericana de Derecho de Familia y de las Personas. Professor no CEU LAW School. Professor na Escola Superior de Advocacia da OABSP.

\section{RESUMO}

Objetivo: O estudo objetiva compreender e apresentar o desenvolvimento dos direitos da personalidade; para tanto, parte-se da perspectiva de São Tomás de Aquino e sua trajetória durante o transcurso da história até a compreensão de que os direitos da personalidade são, e somente são, aqueles direitos encarnados na pessoa cuja concepção basta para afirmar como tal.

Metodologia: Para atingir os fins esperados, a metodologia utilizada é bibliográfica, adotando-se como marco teórico São Tómas de Aquino, especialmente pelo fato de ter reflexionado que persona significat id quod est perfectissimum in tota natura.

Resultados: Com alicerce na teoria dos direitos da personalidade, o artigo aborda a pesquisa científica, na medida em que atesta a existência de um patrimônio moral, que podem ser definidos como os direitos extrapatrimoniais porque não encontram, puramente, estimativa em pecúnia - senão quando lesionados e para efeito compensatório ou por motivo de cessão das potencialidades econômicas, que com o direito em si não se confunde —, razão pela qual revelam influxo pecuniário.

Contribuições: A contribuição central do presente trabalho cinge-se em apresentar o tema de direitos da personalidade como reconhecimento, indisputavelmente sedimentado, do apreço pela pessoa que orientou e orienta os codificadores 
constitucionais e privados. O index de direitos postos em Constituições nacionais concerne, originariamente, à proteção endereçada ao particular versus Estado, bem como, reitera que os direitos personalíssimos (vida, inteireza física e espiritual, liberdade, honra, imagem, privacidade, identidade e direito moral do autor de obra intelectual, v.g.) estão compreendidos na listagem a que a Constituição Federal dedicou um rol fundamental, mas não são os únicos ali postos.

Palavras-chave: Direitos da personalidade; São Tomás de Aquino; Código Civil brasileiro.

\section{ABSTRACT}

Objective: The study aims to understand and present the development of personality rights starting from the perspective of Saint Thomas Aquinas and his trajectory during the course of history until the understanding that the rights of the personality are, and only are those rights embodied in the person whose conception is enough to affirm as such.

Methodology: To achieve the expected ends, the methodology used is bibliographic, adopting the theoretical framework of Saint Thomas Aquinas, especially because it reflected that persona significat id quod est perfectissimum in tota natura.

Results: Based on the theory of personality rights, the article addresses scientific research, insofar as it attests to the existence of a moral heritage, which can be defined as extra-patrimonial rights because they do not find, purely, an estimate in pecuniary - unless when injured and for compensatory effect or due to the assignment of economic potentialities, which is not confused with the law itself which is why they reveal a cash inflow.

Contributions: The central contribution of this paper is limited to presenting the theme of the personality rights as a recognition indisputably sedimented of the appreciation for the person who guided and guides the constitutional and private codifiers. The index of rights placed in national constitutions concerns, originally, the protection addressed to the private versus the State, as well as, it reiterates that the very personal rights (life, physical and spiritual integrity, freedom, honor, image, privacy, identity and moral law of the author of intellectual work, v.g.) are included in the list to which the Federal Constitution dedicated a fundamental role, but they are not the only ones placed there.

Keywords: personality rights; Saint Thomas Aquinas; Brazilian Civil Code. 


\section{INTRODUÇÃO}

Há quase oito séculos São Tomás de Aquino reflexionou que persona significat id quod est perfectissimum in tota natura ${ }^{1}$. A perfeição superlativa que da essência da grei humana retirou São Tomás foi, por séculos, incipientemente, e agora é, com apreço e técnica aprimorados, o fundamento supremo da tutela que se lhe defere através dos direitos da personalidade, vistos e revistos na medida da evolução e da maturação jurídicas.

Não há pessoa que dispense os direitos mais preciosos que se the aderiram com a automática aquisição da personalidade, que do nascimento com vida entre nós deflui ${ }^{2}$.

Não é, puramente, a qualidade do direito fruído que o classifica como da personalidade. Há direitos de qualidade diversa, sejam reais ou de família que, conquanto integrantes de ordem especial, em conteúdo e finalidade, não se revestem dos necessários característicos para se os considerarem como da personalidade. Da personalidade são, e somente são, aqueles direitos encarnados na pessoa cuja concepção basta para os afirmarem como tal. São direitos cujo núcleo fundamental é o corpo e o espírito dos quais derivam irremovíveis necessidades de proteção impostas pela própria e suficiente razão humana (proteção à vida, inteireza física e psíquica, liberdade, honra, imagem, privacidade,

\footnotetext{
1 In Summa Theologica, I, q. 29, a. 3.

2 Entre nós (CC, art. 2ำ e, antes, CC/1916, art. $4^{\circ}$ ), a exemplo doutros sistemas (Alemanha: BGB, §

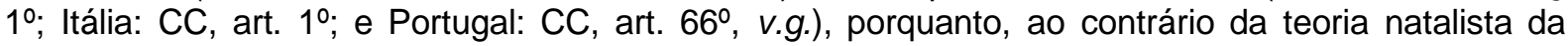
personalidade cá também acolhida, prevalece a teoria concepcionista segunda qual a personalidade aflora incontinenti ao surgimento do conceptus. Na Suíça, e a despeito da primeira alínea do art. 31 do Code Civil (que afiança a aparecimento da personalidade "com o nascimento completo da criança viva"), firmou-se, na alínea seguinte e final, que "a criança concebida goza os direitos civis, com a condição de que nasça viva", de sorte a revelar a adoção da teoria da personalidade condicionada. $\mathrm{O}$ Código Civil francês, servindo-se de impreciso e injustificado rigor, reclama o "nascimento viável", sem o qual não se defere "nenhuma ação" pertinente à filiação (CC, art. 311-4), tampouco direito de sucessão (CC, art. 725). Com rigidez demasiada, o art. 30 do Código Civil espanhol encarece que, "para efeitos civis, só se reputará nascido o feto que tiver figura humana e viver vinte e quatro horas inteiramente desprendido do seio materno". Sobre os nascituros e os direitos em apreço, consultar, por todos, um dos pioneiros estudos nacionais conduzidos por AAASP, 1992, p. 22-3, e Tutela Civil do Nascituro. São Paulo: Saraiva, 2000.
} 
v.g.) ${ }^{3}$ ou social: fala-se da pessoa jurídica, que direitos dessa envergadura também titulariza, se conectados ao desideratum a que se endereçam suas atividades (privacidade, imagem e honra, v.g.) 4 .

Pode-se classificá-los, preservados outros enquadramentos mais ou menos extensos ${ }^{5}$, como compostos em dois grupos. Dentro dos direitos à integridade física: direito à vida, ao corpo (à saúde ou inteireza corporal, aí compreendidas as partes que podem ser isoladas do corpo), direito à destinação do cadáver. Dentro dos direitos à integridade moral ou espiritual: direito à liberdade (liberdade de consciência, de manifestação do pensamento, de crenças e de religião, e de ser informado), direito à honra, à privacidade (intimidade e segredo), à imagem, à identidade pessoal (à ancestralidade e ao sobrenome) e direito moral de autor de obra intelectual ${ }^{6}$.

Os direitos da personalidade são aqueles indispensáveis ao pleno e saudável desenvolvimento das virtudes biopsíquicas da pessoa. Acompanham-na do início ao terminus da personalidade, que com a morte biológica fenece (CC, art. $6^{\circ}$ ). Alguns, como a honra, imagem e direito moral do autor de obra intelectual perpetuam-se através dos sucessores do finado ${ }^{7}$. São, pois, vitalícios.

São direitos que aderem à pessoa - que se pessoa é, personalidade passou a ter -, com o primeiro vagido ou inicial sopro de vida.

\footnotetext{
${ }^{3}$ Da sensibilidade de Battaglia (Curso de filosofia del Derecho, trad. Eliás de Tejada y Lucas Verdú, Madrid, 1951, v. 2, p. 181), citado por Tobeñas (1952, p. 16), colhe-se, com razão símile à que se enxerga para a construção art. 16 do Código civil Austríaco (influenciado por Kant), que "não se pode destruir as exigências perenes do homem nem deixar de reconhecer um núcleo essencial de motivações ineludíveis e primárias, as que fazem que o homem seja homem".

${ }^{4}$ A Declaração francesa erguida em 26.08.1789 ao tempo em que consagrou direitos diversos direitos da personalidade ao longo de seus dezessete artigos, expressou, no art. $6^{\circ}$, que "todos os cidadãos têm o direito de concorrer pessoalmente, ou por seus representantes, à sua formação [...]". É indisputável registro valorativo da tutela ao desenvolvimento da personalidade tal qual, bem após, se leria nas Constituições Italiana (1947, art. 2o), Alemã (Lei Fundamental, 1949, art. 2o, 1), Portuguesa (1976, art. 26) e Espanhola (1976, art. 10), v.g. Todas as traduções lidas neste trabalho são nossas.

${ }^{5}$ Entre nós, são precursores no estudo do tema: FRANÇA, 1992, p. 10-1; também, com mesmo título, in RT 567/11-6; BITTAR, 1995, p. 63-4; GOMES,1966, p. 8-10. Na doutrina estrangeira, ver CARBONNIER, 1996, p. 134; CUPIS, 1961, passim; GANGI, 1946, p. 158 e s.; MAZEAUD, et. al., 1997, p. 378 e s.; CIFUENTES, 1995, p. 22.

6 Em nosso JABUR, 2000, p. 108. Há quem sustente a existência e autonomia do direito (da personalidade) à voz (LEONARDI, 2013, p. 104 e s.).

${ }^{7}$ No que o último concerne, Lei no 9.610/98, arts. 5으, VIII, e, e $24, \S 1^{\circ}$.
} 
Revelam-se incondicionais (MONTEIRO, 2003, p.97). A intervenção humana positivadora não lhes suprime nem acresce dimensão, tão-só os consagra, porque preexistentes e pertencentes à pura razão ${ }^{8}$. Por isso, inatos.

Essenciais, porque não se os pode dispensar, sobreditos direitos são também irremovíveis ou irrenunciáveis ${ }^{9}$ : deles a pessoa não será despojada, por vontade ou imposição, mesmo de lege lata (CC, art. 11) ${ }^{10}$.

Fora do comércio, são inalienáveis, de sorte a não se prestarem à mercancia ou à transmissão ${ }^{11}$. Por conseguinte, mostram-se intransferíveis. Dos atributos pessoais de Caio, não poderão recolher proveito Tício ou Semprônio, porquanto nele encarnados e dele inseparáveis ab origine. Daí inexecutáveis, o que Ihes comunica, pelas mesmas razões, a impenhorabilidade e a consequente inexpropriabilidade, posto atrelados indissoluvelmente à pessoa.

Embora servíveis à exploração econômica através das potencialidades neles agregadas (uso da imagem, da privacidade e a divulgação ou utilização de obra intelectual, v.g.), os direitos em apreço não permitem transferência de titularidade. $O$ poder pessoal de disposição defluente do aproveitamento das virtudes comerciais mediante consentimento do titular confina-se, sempre, à parcial e temporária concessão. São direitos relativamente indisponíveis.

A fruição que à pessoa se reconhece sobre as personalíssimas projeções e manifestações produzidas pela dimensão da própria personalidade torna os direitos que dela decorrem imprescritíveis. A imprescritibilidade aí implicada pela mesma razão que a tais e sublimes direitos se consagrou a essencialidade ou vitaliciedade concerne ao gozo das virtudes que a personalidade defere, não ao direito subjetivo

\footnotetext{
8 O Código Civil austríaco (ABGB, 1811), sob a influência de Kant, fixou em seu art. 16 que "Todo homem tem direitos inatos que se fundam na razão, em função da qual deve ser considerado pessoa".

${ }^{9}$ Ligam-se à pessoa "de maneira perpétua e permanente" (Silvio Rodrigues, Direito Civil. 34ed., atual. São Paulo: Saraiva, 2003, v. 1., p. 61).

${ }^{10} \mathrm{O}$ direito à prestação alimentícia, corolário do direito à vida e à integridade física, mereceu atenta e apurada dicção no Código Privado em vigor, que the expressou abrangente proteção, enunciandoIhe, conquanto desnecessariamente, a irrenunciabilidade, intransmissibilidade, impenhorabilidade e posição fora de comércio (art. 1.707).

11 O Preâmbulo da Declaração francesa de 1789 considerou os direitos humanos como "naturais, inalienáveis e sagrados do homem".
} 
de aforar ação para compensar dano. A tutela para cessação da ameaça, posto diversa, gravitará conformemente à duração da promessa de malefício. Já o momento do dano fixa o marco a quo da postulação compensatória ${ }^{12}$.

Os direitos examinados opõem-se a todos. Mas não se deve considerá-los absolutos. São, em vez disso, oponíveis erga omnes. É imprópria a atribuição de vocábulo absolutos, como já afirmamos (JABUR, 2000a, p.68-74). O obséquio aos direitos da personalidade alheios é ressonância do respeito infundido pela própria dignidade humana, que impele, para seu reconhecimento e consagração jurídicos, a proteção e a tutela genuínas da personalidade ${ }^{13}$. Direito nenhum é absoluto. Nem o direito à vida pode ser absolutizado, conquanto primeiro e maior atributo da pessoa. E com ele assim também é por motivo biológico e por causa jurídica. Entre a vida da gestante e a do nascituro, a opção por uma, com a insuperável morte da outra, evidencia a indisputável fragilidade da vida, ou a defectividade das técnicas humanas, além da superior condição divina. Por razão jurídica, porque pena de morte, em excepcionais ocasiões, há (CF, art. 5ำ, LXVII, a). Se nem o direito à vida poderia ser brindado com o sinal de supremacia, menos ainda e decerto poderão ser considerados inexoráveis os direitos da personalidade, que, debaixo e a partir dela, se revelam.

Por essas sintetizadas razões, retiram-se os direitos da personalidade do domínio patrimonial. Entendem-se-os, pois - e a doutrina quase indivisível -, extrapatrimoniais. A respeitada divergência se apresenta através de Henri, Léon e Jean Mazeaud e François Chabas, que atestam a existência de um patrimônio moral 14.

São direitos extrapatrimoniais porque não encontram, puramente, estimativa em pecúnia - senão quando lesionados e para efeito compensatório ou por motivo

\footnotetext{
${ }^{12}$ Segundo Maria Helena Diniz (2004, p.121), a imprescritibilidade não se extingue "nem pela inércia na pretensão de defendê-los [...]".

${ }^{13}$ Francesco Ferrara (1921, p.395) chegou a considerar que o objeto dos direitos da personalidade é a obrigação que aos outros indivíduos se impõe ao respeito das manifestações que dela decorrem

14 "Por oposição aos direitos pecuniários, os direitos da personalidade têm, sobretudo, um valor moral. Eles constituem aquilo que se poderia chamar de patrimônio moral (MAZEAUD, 1997, p. 371).
} 
de cessão das potencialidades econômicas, que com o direito em si não se confunde - razão pela qual revelam influxo pecuniário.

O patrimônio compreende o poder de transferibilidade de que falou Andreas von Tuhr ${ }^{15}$.

Por isso, e na expressão de San Tiago Santas, ditos direitos apresentam-se "inestimáveis, o que quer dizer que eles não têm um equivalente exato em dinheiro" (DANTAS, 1979, p.194).

Os direitos da personalidade dela não são, mas da pessoa, único sujeito de direitos ${ }^{16}$. É através da personalidade, que os suporta e os justifica juridicamente, que são projetados os direitos indispensáveis ao integral desenvolvimento das virtudes somáticas e anímicas ${ }^{17}$. Essa aparente contradictio in terminis, agregada ao quilate do conteúdo e à magnitude da expressão dos direitos aqui estudados, orienta a preferência pela designação direitos personalíssimos, posta por Rotondi, Pugliatti e Coberllini, acentuada por Chiovenda ${ }^{18}$ e superiormente articulada por Cifuentes (1995, p.196-197). A expressão direitos da personalidade foi proposta por Gierke (Persönlichkeitsrechte) e desenvolvida por Coviello (CIFUENTES, 1995, p.195). O elo que se evidencia entre o sujeito e os direitos que dele dimanam é tão forte que o emprego do adjetivo em seu máximo grau (superlativo absoluto sintético) se apresenta consentâneo com o conteúdo neles encarnado, distante de qualquer outro direito, mesmo dos de Família, que se dedicam à pessoa, integrada e interagida em sociedade, porém, e com intensidade maior, também pretextam, para a tutela que deles se queira extrair, a própria existência da personalidade.

É a "íntima adesão ao sujeito", bem-posta por Cifuentes (1995, p.196), que os superpõe a qualquer outra classe de direitos de ordem patrimonial ou não. De

\footnotetext{
${ }^{15}$ Segundo quem, e com sobra de razões, "patrimônio é poder econômico" (TUHR, 1946, p. 385).

${ }^{16}$ A personalidade humana, escreve Paulo Mota Pinto (2003, p.15), é "objecto de protecção enquanto centro autónomo de decisão ou, também na expressiva formulação de Orlando de Carvalho, 'raiz de um poder de autodeterminação"'.

${ }^{17}$ A personalidade não é nem tem direito. Dela, como ossatura, é que os jura decorrem e por causa dela é que também se reconhecem esses superlativos mas não absolutos direitos. Porque em virtude dela, natural e necessário antecedente, é que surgem. São conseqüência da existência da pessoa, cuja personalidade, ipso facto, irradia direitos. Titular, única, é a pessoa.

${ }^{18}$ Para o qual, e "entre todas", a expressão "é a mais breve e inequívoca e designa direitos absolutos não-reais" (CHIOVENDA, 1922, p. 51).
} 
mais a mais, quer direitos da personalidade, quer de personalidade - como preferem portugueses e alguns alemães —, implica ideia de posse, que com tal especialidade de direitos, como atrás se pôs, não convive. Neles não se enxerga jus disponendi, tampouco jus possessionis, porque é defesa a transmissão ou transferência do conteúdo do direito.

Aos direitos personalíssimos são frequentemente associadas as liberdades civis (DELEURY; GOUBOU, 1997, p.55). Delas diferem, todavia. Embora a vocação endereçada ao bem-estar da pessoa os assimile e aproxime ${ }^{19}$, o agente violador que caracteriza cada espécie de direito protetivo da pessoa os diferencia.

\section{NATUREZA JURÍDICA}

Não há Constituição Federal ou Lei Fundamental genuína e produzida em obséquio ao Estado de Direito na qual não se enxerguem insertas previsão e tutela das menores ou maiores expressões da personalidade humana 20.

O reconhecimento, indisputavelmente sedimentado, do apreço pela pessoa orientou e orienta os codificadores constitucionais e privados. $\mathrm{O}$ index de direitos

19 O direito ao bem-estar é cláusula inserta na Declaração de 1948 (art. 25). Como também o é o próprio desenvolvimento da personalidade (art. 29) que dele depende. A Convenção Americana de 1969 (Pacto de São José) rediz que "toda pessoa tem direito ao reconhecimento de sua personalidade jurídica" (art. $3^{\circ}$ ).

20 Múltiplas, exemplificativamente, são as desinências, vistas em Constituições nacionais, identificadoras das liberdades públicas cujo núcleo são os direitos fundamentais da pessoa: Direitos fundamentais (Irlanda, 1937), Princípios fundamentais (Itália, 1947), Direitos fundamentais (Alemanha, 1949), Liberdades públicas e direitos fundamentais (Grécia, 1975), Direitos e deveres fundamentais (Portugal, 1976; Espanha, 1978), Direitos e deveres constitucionais (Chile, 1980), Declarações, direitos e garantias (Argentina, 1994) e Direitos Fundamentais (Finlândia, 2000). A Constituição Belga, de 1831, incorpora a tutela aos direitos em apreço mediante título a que atribuiu a rubrica Dos Belgas e seus Direitos. Semelhante designação acolheu a Constituição Luxemburguesa, de 1868 (Dos Luxemburgueses e seus direitos), cuja nação, entre 1831 e 1839, pôs-se debaixo da Constituição Belga. Antes, até 1830, a Bélgica e os Países-Baixos, conforme Congresso de Viena, formavam o Reino dos Países-Baixos cuja atual e revisada Constituição, de 1983 (originariamente de 1814), dedica ampla proteção aos direitos fundamentais da pessoa em seu primeiro Capítulo, denominado Direitos fundamentais. A Constituição Francesa, de 1958, por expressa disposição contida em seu Préambule, refere e anexa, fazendo-se a ela integrar, os "princípios de soberania national tais como foram definidos pela Declaração de 1789, confirmados e completos pelo preâmbulo da Constituição de 1946". 
postos em Constituições nacionais concerne, originariamente, à proteção endereçada ao particular versus Estado. Nem todos direitos fincados no rol fundamental das sobreditas Constituições são, como o são os direitos da personalidade, indispensáveis ao pleno e saudável desenvolvimento das virtudes psicofísicas. O catálogo de direito fundamentais, assim entendidos aqueles fixados em Constituições nacionais, embora também vocacionados ao apreço e ao bemestar da pessoa, importariam tratamento de direito público (TOBEÑAS, 1952, p.13). Já se os considerou "direitos de dupla face, pública e privada", que se apresentam ao Direito Civil quando vistos em relação jurídica entre particulares em virtude de contrato ou ato ilícito (GOMES, 1966, p.7).

Das liberdades públicas, surgidas com a consagração dos direitos individuais ou fundamentais (e assim surgem quando transferidos do Direito Natural para o Positivo) (RIVERO, 1973, p.17), distinguem-se as liberdades privadas, oponíveis aos particulares (CRETELLA JÚNIOR, 1986, p.22).

Os direitos de cuja tutela ocupam-se as Constituições nacionais têm sentido mais largo, que depassa os particulares e indispensáveis elementos constitutivos e preservadores da personalidade para ingressar no domínio político-social endereçado às relações em virtude das quais o Estado possa lesar ${ }^{21}$.

Deveras, os direitos personalíssimos (vida, inteireza física e espiritual, liberdade, honra, imagem, privacidade, identidade, direito moral do autor de obra intelectual, v.g.) estão compreendidos na listagem a que nossa Constituição Federal dedicou rol fundamental, mas não são os únicos ali postos. Apresentam-se ladeados doutros direitos, igualmente projetados à proteção da pessoa e de similar status e igual envergadura cuja essência, entretanto, orienta-se por política legislativa que ultrapassa a virtude de fornecer à pessoa aquilo, e tão-só aquilo, que the é indispensável ao integral e pleno desenvolvimento do corpo e do espírito, das

${ }^{21}$ Sobre a inserção dos direitos personalíssimos num (público) ou noutro (privado) domínio, Elimar Szaniawski anuncia a injustificada dicotomia entre Direito Público e Privado, no qual, por funcionar como depositário dos princípios gerais do direito, conforme lição que colhe de José Oliveira Ascensão (1978, p. 261), teria ali, no Direito Civil propriamente, seu campo adequado de inserção (SZANIAWSKI, 1993, p. 94). Mas sustenta logo à frente que "os direitos da personalidade não são nem públicos nem privados. São simplesmente direito da personalidade". Seriam, de tal sorte, "direitos subjetivos de natureza especial" (SZANIAWSKI, 1993, p. 95). 
potencialidades físicas e psíquicas, das projeções exclusivas da personalidade, sobretudo do ser humano, sem as quais não alcança a pessoa a fruição plena e o aproveitamento adequado e intangível da ordem natural da vida.

Brevissimamente, poder-se-ia distinguir os direitos personalíssimos (direitos subjetivos privados) daqueloutros fundamentais (direitos subjetivos públicos) em atenção e função do agente violador: quando com ele se identifica o Estado, de direito público se cuidará; se quem o viola é o particular, de direito privado haverá de se tratar.

São, entre nós, da personalidade, embora debaixo da tutela pública, e por isso direitos públicos subjetivos, os direitos postos, por exemplo, sob os comandos dos incisos II a XXI e XXVII a XXIX do art. 5 da Constituição Federal. Mas não o são aqueles que dedicam tutela à propriedade (incisos XXII a XXVI e XXX do mesmo artigo). A defesa do consumidor, comandada em mais de uma oportunidade pela Constituição Brasileira (arts. 5ํㅡ, XXXII, e 48 do Ato das Disposições Constitucionais Transitórias), inclusive postada como princípio da ordem econômica (art. 170, V), é direito de magnitude superior, porque implica proteção às relações jurídicas entre fornecedores e consumidores, que hodiernamente prevalecem, mas fundamental à evolução e ao livre desenvolvimento da pessoa não é. E não o é, assim como o direito de herança (art. 5o, XXX), v.g., porquanto a projeção das potencialidades físicas ou anímicas que defluem da personalidade, e apenas dela dimanam, não agregam componentes de índole pecuniária, tirantes as hipóteses de compensação do dano ou apreciação das potencialidades econômicas de um direito personalíssimo. O que se entende como emanação da personalidade entende-se como completamente desapegado ou desvinculado de qualquer expressão econômica ou material (só valorável e valorizável quando se compensa lesão a direito personalíssimo ou se apura o quantum correspondente da expressão comercial, frise-se e frise-se bem) ${ }^{22-23}$.

\footnotetext{
22 Henri, Léon e Jean Mazeaud e François Chabas assim diagnosticam a diferença entre uma e outra sorte de direitos: "Confundem-se freqüentemente direitos do homem e direitos da personalidade. É um erro. Alguns direitos pecuniários, embora não constituam direitos da personalidade, tal o direito de propriedade, são considerados essenciais ao homem. Em contrapartida, se a maior parte dos direitos
} 
A proteção integral da pessoa e tudo aquilo que sua estrutura exige para o bem-estar é, sem rebuço de dúvida, o que perseguem os direitos fundamentais e os direitos personalíssimos. Essa compreensível preocupação, renovada a cada dia com as manifestações interiores do sujeito exclusivo de direitos, desdobra-se em plúrimas terminologias, ora realçando a conotação pública da tutela, ora enfatizando seu caráter privado. É salutar que seja larga a política protecionista da pessoa vis-àvis dos poderes constituídos pelo Estado e ao Estado, natural destinatário da abstenção de ordem genérica que ditos direitos humanos ou fundamentais prescrevem, tal qual os privados estabelecem. Os direitos da personalidade seriam, de tal sorte, parcial expressão dos direitos fundamentais ou humanos perante os particulares, não, propriamente, esfera ou ramo daqueles ${ }^{24}$.

da personalidade, em razão do estreito vínculo com o seu titular, são direitos do homem, alguns não têm o caráter primordial: o 'direito à própria imagem', que nos permite nos opor à reprodução de nosso retrato, não é um direito do homem. É preciso, sobretudo, compreender que, quando se estudam os direitos do homem, trata-se, essencialmente, de relações de direito público: protegem-se os direitos essenciais do indivíduo contra o arbítrio do Estado; nominam-se-os, freqüentemente, 'liberdades públicas'. Quando se examinam os direitos da personalidade, está-se, sem dúvida, habitualmente, em face dos mesmos direitos, mas sob o ângulo do direito privado, é dizer, das relações entres particulares; trata-se de defender esses direitos não mais contra a domínio da autoridade, mas contra os atentados aí sentidos pelos nossos semelhantes" (MAZEAUD; et. al., 1997, p. 377-8).

${ }_{23}$ José Serpa de Sta. Maria embute os direitos personalíssimos como espécie cujo gênero são os direitos humanos: "Os direitos humanos são aqueles direitos fundamentais da pessoa humana, de larga abrangência e que englobam inclusive, os direitos da personalidade de maior interesse civilista, do que de ordem pública constitucional (social e política), ou pública penal. São eles as balizas estruturais que compõem com todos estes últimos em seus vários matizes o painel dos direitos fundamentais da pessoa humana" (Direitos da personalidade e sistemática civil geral. Campinas: Julex, 1987, p. 35).

$24 \quad$ Paulo Mota Pinto encarece a influência produzida pelos direitos subjetivos públicos no direito privado: "Na verdade, os direitos da personalidade desempenham uma função, de instrumento jurídico de concretização dos direitos fundamentais no direito privado, que deste modo (para utilizar uma metáfora já comum) 'irradiam' através deles para a ordem jurídico-privada. Tal não significa que a sua previsão seja inútil, ou redundante, perante aqueles - e mesmo numa perspectiva segundo a qual o direito civil, como todos os ramos do direito, é necessariamente também 'direito constitucional concretizado' -, ou que seja consumida pela previsão dos direitos fundamentais em nível constitucional. Na verdade, a imposição de níveis de protecção adequados às exigências dos direitos fundamentais, também no direito privado, conjugada com a rejeição da rigidificação e da inflexibilidade da vida jurídico-privada, que resultaria de uma 'substituição do direito civil pelo direito constitucional', tornam hoje inaceitáveis, a meu ver, seja as posições de equiparação da actuação dos particulares no direito privado à das entidades públicas, seja aquelas que vêem os direitos fundamentais como dirigidos apenas aos entes públicos, requerendo antes soluções diferenciadoras" (ob. cit., p. 10-1).

Revista Jurídica Unicuritiba. Curitiba.V.01, n.58, p.434-488, Jan-Mar. 2020 [Received/Recebido: Outubro 23, 2018; Accepted/Aceito: Setembro 21, 2019] 
Os direitos personalíssimos ou da personalidade são direitos subjetivos privados. Essa a natureza jurídica que os envolve. $O$ fato de serem inatos (como nenhum outro direito, porquanto independentes de posterior aquisição), essenciais (ligados ao mecanismo de desenvolvimento pleno e à expansão da personalidade), além de vitalícios, posto acompanharem - justamente porque essenciais - a pessoa durante o curso de sua existência, sem embargo do exercício ad perpetuam, e pelos herdeiros do titular finado, de alguns direitos que se eternizam imiscuindo-se àqueles titularizados pelo próprio sucessor, autoriza referi-los como direitos privados subjetivos autônomos.

Entre os diversos empeços em que se escorava a ultrapassada concepção segundo a qual os direitos aqui cuidados não se inseriam no conceito ou conteúdo dos direitos subjetivos - também Savigny, Andreas von Tuhr, Enneccerus e Ravà negaram a própria existência desses direitos —, colhe-se, em Paul Roubier (1963, p.10 e 12), também criticado por Pierre Kayser (1971, p.452), que os direitos subjetivos, posto emanados da lei ou da voluntas dos particulares, não se embutiriam situações "estabelecidas de autoridade em vista do bem comum, e não para o serviço dos interesses individuais", as quais, numa expressão cognominou de situações objetivas. Nos direitos subjetivos, preestabelecidos, identifica-se, entre outras prerrogativas atribuídas ou titular, a dispor, por conseguinte, a de renunciar (decerto distante dos direitos personalíssimos, inapelavelmente irrenunciáveis). As situações objetivas evidenciam-se em decorrência de uma simples reação da lei contra um fato ou ato jurídico ${ }^{25}$.

\footnotetext{
${ }^{25}$ Roubier não enxerga nas situações objetivas senão um "sistema de poderes e deveres criados pela via da autoridade em vista do bem comum. Ao contrário, os direitos subjetivos são particularmente numerosos em direito privado onde a iniciativa privada, ajudada pelo princípio da autonomia da vontade nos contratos, tem um campo de ação considerável" (ROUBIER, 1963, p. 15). À frente, reencarece que a noção de direito subjetivo, sempre apropriável, conecta-se ao caráter pecuniário do direito, motivo por que exclui alguns direitos da personalidade (ROUBIER, 1963, p. 365), a cujo titular nada mais se atribui (sem nominá-los de direitos) senão "interesses legítimos" que inspiram "poderes e deveres", meras "prerrogativas" (ROUBIER, 1963, p. 365-7). Aos direitos concernentes aos "atributos de ordem intelectual e moral", Roubier reconhece "um direito no sentido próprio do termo, e não simplesmente um interesse legítimo, sancionado por uma ação judicial" (ROUBIER, 1963, p. 374). A contradição de Roubier aparece pouco adiante, ao então afirmar que, excluídos o "direito moral sobre as obras artísticas e literárias" e o "direito ao nome", que convergem "um elemento concreto e exterior que pode servir de assento ao direito", as demais manifestações da
} 
De modo que por muitos foi negada a qualidade de direitos subjetivos aos direitos personalíssimos nos quais não se enxergava a existência de uma facultas concedida pelo direito objetivo ao titular em cujo benefício surgiria um direito, então subjetivo, tão-só em decorrência da violação de um direito personalíssimo. Todavia e sem bem examinados, os direitos personalíssimos evidenciam, ab ovo, múltiplas possibilidades de utilização ou fruição, todas, decerto, atentas à temporal e parcial concessão ou permissão, graciosa ou onerosa, para exploração das potencialidades ou virtudes econômicas contidas na essência desses direitos privados sui generis e autônomos. A autorização para divulgação da imagem, penetração na privacidade e utilização do proveito pecuniário do direito de autor exemplificam, sem aplicado esforço, a multifária aptidão que os direitos personalíssimos concentram mediante a limitada exploração que se Ihes defere sua relativa disponibilidade.

E o direito privado é o terreno adequado para o tratamento e compêndio das regras concernentes à proteção da pessoa em virtude das relações sociais nas quais se insere frente ao particular ${ }^{26}$. Por isso a introdução, no primeiro Livro da Parte Geral do Código Civil, de Capítulo especificamente dedicado aos direitos personalíssimos.

personalidade, por ele examinadas (imagem, honra e integridade física), distanciar-se-iam de qualquer reconhecimento, posto despidas de componentes de direito legítimo (ROUBIER, 1963, p. 375). O que ora se colhe não se harmoniza com a rejeição do nome no index dos direitos personalíssimos visto páginas antes em que isso foi escrito considerando que "o nome não pode ser um objeto de propriedade, porque se trata de um valor incorporal", de sorte a se verificar uma inconciliação do direito ao nome não apenas com o direito de propriedade, "mas também com a definição de direitos subjetivos" (ROUBIER, 1963, p. 367). Ao fim do exame do direito ao nome, ainda frisa: "É, em nossa opinião, uma tentativa de acordo entre a teoria da propriedade do nome e aquela do nome situação objetiva; mas nada resulta de claro, nem naquilo que concerne aos sujeitos, nem naquilo que concerne ao objeto desse pretendido direito" (ROUBIER, 1963, p. 368). Se de pretendido e não de efetivo direito se cuida, como quis Roubier, não se poderia enxergar o direito ao nome, ao lado doutra exceção representada pelo "direito moral sobre obras artísticas e literárias", como duas hipóteses em que se enxerga "um elemento concreto e exterior que poder servir de assento ao direito, a saber, o nome de família de um lado, a obra do espírito, de outro".

${ }^{26}$ Adriano de Cupis $(1961$, p.45) enfatiza que a disciplina civilística dos direitos da personalidade corresponde "a uma exigência que lhes é natural" e em virtude da qual se "Ihes assegura a proeminência relativamente a todos os outros direitos da pessoa a que respeitem". 


\section{ESTRUTURA E CONTEÚDO FIXADOS PELO CÓDIGO CIVIL}

A liberdade é o primeiro e maior atributo que da vida deflui. Insondável e multiforme, orienta-se ao sabor das particulares volições e idiossincrasias, dos caracteres e recalques agregados pela personalidade psicossocial humana. Dessa personalidade, produto da vida, distingue-se outra, jurídica, que, no direito doméstico, se adquire, consoante já se examinou, com o primeiro vagido, com o primeiro sopro de vida (CC, art. $\left.2^{\circ}\right)$.

A personalidade jurídica serve de estrutura a que aderem, simultaneus tempus, os direitos que ornamentam a pessoa. A eles o Código Civil, sistematizando-os, dedicou onze artigos (CC, arts. 11 a 21$)^{27}$.

$\mathrm{O}$ apreço à personalidade humana é a primeira e primordial missão do lidador do direito que tem "personalismo ético como seu epicentro" (PINTO, 2003, p.7). O tratamento dos direitos personalíssimos mostra-se crescentemente apurado e intenso. É razão por que António Menezes Cordeiro $(2001$, p.1) nisso detecta um "surto doutrinal e jurisprudencial".

O Código Civil incorporou parte dos dezesseis artigos apresentados por Orlando Gomes em seu Anteprojeto de 1963 (arts. 29 a 37 e 38 a 44), pondo-os sob o Capítulo Dos direitos da personalidade.

\footnotetext{
${ }^{27}$ Existente em sua forma pouco mais apurada, embora assistemática, já era, cá, a tutela dos direitos personalíssimos, antes e após a democrática Constituição Federal de 1988. Registram-se, como exemplos de leis ordinárias endereçadas à proteção em apreço, a Lei no 5.250/67 (arts. 20 a 22, 24, 25, 29, 35 e 49), que regra a liberdade de manifestação do pensamento (a Lei ํo 4.117/62, ou Código Brasileiro de Telecomunicações, revogado pela Lei no 9.472/97, também dedicava similar proteção), a Lei oㅜ 7.232/84, que fixou a Política Nacional de Informática (art. 43), a Lei no 8.069/90, ou Estatuto

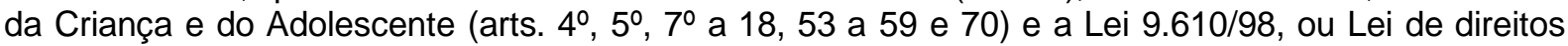
autorais (arts. 1ำ $7^{\circ}, 24,27$ e 28), entre múltiplos outros documentos legislativos vocacionados à tutela então esparsa da personalidade jurídica.
} 


\section{A CONSTRUÇÃO DO ART. 11: ROL ABERTO, CARACTERÍSTICAS DECLARADAS E LIMITAÇÃO NELE FIRMADA}

O Código não enumerou direitos da personalidade em dispositivo inaugural ou a ele sucessivo de sorte a introduzi-los ou mesmo enfeixá-los através de um único artigo. Preferiu referir e embutir, em diversos preceitos, adequada proteção que já lhes deferia o sistema jurídico doméstico.

Assim também fizera o legislador português de $1966^{28}$, que encabeçou - rol de direitos personalíssimos trazidos pelo Código Civil (que dedicou coincidentes onze artigos ao instituto) com cláusula geral de proteção à personalidade (art. $70^{\circ}$ ), que adiante e aqui melhor se examinará igualmente. É tratamento salutar, já dissemos, porque, a par da tutela de ordem genérica, de espectro ampliativo, consideraram-se hipóteses de maior carência ao longo da mesma seção onde se registrou a geral e ampla garantia das expressões físicas e morais da pessoa. São termos vagos e sujeitos à investigação, os quais, todavia, em campo onde a restrição se evidencia temerária, encontram ressonância coerente com a natureza do valores da personalidade. Bem distinto, em estrutura e efeitos, seria um único direito da personalidade, isolado e estanque (JABUR, 2000a, p.100$101)^{29}$.

Diversamente, entre vários, o Código Civil italiano, alemão e francês, tampouco erigiram sistematização aos direitos em estudo. Neles e noutros Códigos, são tíbias as prescrições endereçadas aos superlativos direitos de qualquer

\footnotetext{
${ }^{28}$ Cotejando o tratamento colhido nos Códigos lusitano e brasileiro, Paulo Mota Pinto (2003, p. 19) encarece que "a configuração precisa dos direitos da personalidade - quanto a saber quais existem, como se sistematizam e relacionam, etc. - foi deixada implícita na formulação geral do artigo 11 . Quis-se, certamente, para além de reduzir dúvidas, evitar uma enumeração que pudesse ser considerada taxativa", conforme também acentua, acresce esse autor português, Gustavo Tepedino (1999, p. 36).

${ }_{29}$ Entre os 186 artigos do Novo Código alcançados pelo Projeto de Lei no 6.960/02, pretende-se alargar 0 art. 11 para nele também se embutirem nominados direitos da personalíssimos. $O$ texto proposto é assim redigido: "O direito à vida, à integrigade físico-psíquica, à identidade, à honra, à imagem, à liberdade, à privacidade, à opção sexual e outros reconhecidos à pessoa são natos, absolutos, intransmissíveis, indisponíveis, irreunciáveis, ilimitados, imprescritíveis, impenhoráveis e inexpropriáveis. Parágrafo único. Com exceção dos casos previstos em lei, não pode o exercício dos direitos da personalidade sofrer limitação voluntária".
} 
ordenamento jurídico no qual a dignidade tenha primazia. O Code Napoléon autoriza a cessação, sem prejuízo da compensação civil, dos "atentados à intimidade da vida privada" (art. $\left.9^{\circ}\right)^{30}$. O Bürgerlichen Gesetzbuches (BGB) regrou o respeito ao nome, permitindo a ação de abstenção para "cessação da perturbação" (§ 12). Ao cuidar dos atos ilícitos, promoveu a tutela da vida, do corpo, da saúde e da liberdade (além da propriedade que a seguiu na redação), mediante deferimento de "indenização do dano daí resultante" ( $\S 823)^{31}$. O Codice Civile tratou da proteção ao corpo, cuja disposição proibiu quando diminuidora da permanente integridade física (art. $5^{\circ}$ ), do nome, que decerto compõe-se pelo nome e pronome (art. $6^{\circ}$ ) aos quais se defere tutela em caso de uso indevido, inclusive mediante ação para cessação "do fato lesivo" (art. $7^{\circ}$ ) ${ }^{32}$, e da imagem para cuja proteção reclamou (i) a exibição "fora dos

\footnotetext{
${ }^{30}$ A disposição foi introduzida pela Lei no $70-643$ de 17.07.1970. A Lei $n^{\circ}$ 2000-516, de 15.06.2000 criou o art. 9-1 por intermédio do qual "toda pessoa tem direito ao respeito da presunção de inocência". A preceituação, com sobra de razões, foi posta subseqUentemente ao direito à privacidade, porque cuidou do respeito à honra cuja inobservância deriva da quebra da presunção que estabelece. Eis o seu teor: "Quando uma pessoa, antes de qualquer condenação, é apresentada como culpada de fatos que são objeto de uma investigação ou instrução judicial, o juiz pode, ainda que liminarmente e sem prejuízo da reparação do dano experimentado, determinar todas as medidas, tal como a inserção de um retificação ou a difusão de um comunicado, com a finalidade de fazer cessar o atentado à presunção de inocência, o que correrá a expensas da pessoa, física ou jurídica, responsável pelo atentado".

${ }^{31}$ Decênios fluíram para que a ordem jurídica alemã reconhecesse a existência de direitos da personalidade além daqueles acima postos, por muitos até negados, sobretudo na forma de um direito geral de personalidade (Savigny, Andreas von Tuhr, Enneccerus, v.g.). Sustentou-se, em favor da existência da um cláusula geral protetiva da personalidade, a tutela enxergada na segunda alínea do $\S 823$, que estabelecia semelhante obrigação reparatória "àquele que infringiu uma lei destinada à proteção de outro direito", como também, para outros, na proteção aos "bons costumes" (§ 826). A promulgação da Lei Fundamental, ou Constituição de Bonn, em 23.05.1949, estabeleceu novos rumos à jurisprudência alemã. Modelarmente, o art. 1ำ da Lei Suprema (Grund Gesetz), firmou que "a dignidade do ser humano é intangível. Todos os poderes públicos tem a obrigação de a respeitar e de a proteger". E, embora o art. $2^{\circ}$ da Lei Fundamenal estabeleça que "toda pessoa tem direito ao livre desenvolvimento de sua personalidade, contanto que não viole os direitos de outrem nem infrinja a ordem constitucional ou a lei moral", o Tribunal Constitucional (BundesVerfassunsgericht, BverfG) ainda resistiu por muito tempo ao acolhimento de uma cláusula geral, ao contrário do Tribunal Federal (Bundesgerichshof, BGHZ), também consoante rumorosa decisão de 02.04.1957, conforme noticia Nipperdey e Scheffler, em que a proteção da dignidade humana e, por conseguinte, da personalidade foram endereçadas ao Estado tanto quanto ao particular (NIPPERDEY; SCHEFFLER, 1959).

${ }^{32}$ Além da proteção por "interesse fundado em razões familiares dignas de ser protegidas" (art. $\left.8^{\circ}\right)$. O Código Civil italiano protegeu também o pseudônimo que adquiriu "importância do nome" ( $\left(\operatorname{rrt.~} 9^{\circ}\right)$.
} 
casos em que a exposição é permitida por lei" ou (ii) o prejuízo ao decoro ou da reputação (art. 10) ${ }^{33-34}$.

Difere o moderno Código Civil da Província canadense de Quebec (1994), única que o adota, registra no início de seus Primeiro Livro e Primeiro Título (Do gozo e do exercício dos direitos civis) rol aberto de direitos personalíssimos aos quais cometeu o mais extenso index protetor de que temos notícia ${ }^{35}$. A despeito dos quarenta artigos construídos aos direitos personalíssimos (arts. 10 a 49), o legislador quebequense conduziu-se de forma prudente. Não edificou rol hermético. Serviu-se de catálogo aberto como anuncia o Título Segundo do Primeiro Livro do Código (Dos certos direitos da personalidade).

Posta a marca da ausência de confinamento ou declaração de direitos num único dispositivo do Código Civil brasileiro, examinam-se as características por ele atribuídas aos direitos personalíssimos.

$\mathrm{O}$ art. 11 do Código enuncia regra, em si própria excepcionada ("Com exceção dos casos previstos em lei" ${ }^{36}$ ) conforme a qual, e sinteticamente, afirmaram-se três características dos direitos personalíssimos (intransmissibilidade, irrenunciabilidade e ilimitabilidade voluntária ou indisponbilidade ${ }^{37}$ ). E assim são, mas não só intransmissíveis ${ }^{38}$, irrenunciáveis e parcialmente indisponíveis se

\footnotetext{
${ }^{33}$ Sobre o direito de imagem, especificamente em torno das limitações vistas no art. 20 do Código Civil brasileiro, por importação disforme do art. 10 do Código Civil italiano, consultar nosso JABUR, 2003, p. 11-44.

${ }^{34}$ A Constituição Italiana de 1947, posterior ao Codice Civile, de 1942, reencareceu os fundamentos sociais em que se apoiam aquela nação, assim como, e por consequência, o apreço pela dignità sociale que atribuiu, igualmente, a todos os cidadãos (art. $3^{\circ}$ ) motivo por que a "república reconhece e garante o direito à inviolabilidade do homem, seja como indivíduo, seja na formação social onde se desenvolve sua personalidade e se reclama o cumprimento dos deveres inderrogáveis de solidariedade política, econômica e social."

35 "Art. $3^{\circ}$. Toda pessoa é titular de direitos da personalidade, tais como o direito à vida, à inviolabilidade e à integridade de sua personalidade, ao respeito de seu nome, de sua reputação e de sua vida privada."

${ }^{36}$ São exemplos dessas exceção as ressalvas vistas nos arts. 13, 14, 20 e 1.707 do mesmo Código. $\mathrm{O}$ art. $199, \S 4^{\circ}$, da Constituição Federal, regrado pela Lei $n^{\circ} 9.434 / 97$, que se regula pelo Decreto $\mathrm{n}^{\circ}$ 2.268/97, estabelece a maneira e a ocasião em que a disposição do corpos e de suas partes ou produtos poderá ocorrer.

${ }_{37}$ À frente se examinará o conteúdo da indisponibilidade aí fixada mediante restrição à limitação, mesmo que espontânea.

${ }^{38}$ Escreve Ives Gandra da Silva Martins (2003, p.57) que a intransmissibilidade lida no art. 11 é excepcionada pela transmissão ao sucessor da titularidade para a "defesa dos direitos do sucedido,
} 
apresentam, como atrás já se grifou. O legislador, todavia, entendeu suficiente o registro dessas três notas e, por isso, supérflua a ressalva das demais (inatos, essenciais e vitalícios, extrapatrimoniais, inalienáveis, inexecutáveis, impenhoráveis, inexpropriáveis, imprescritíveis e oponíveis erga omnes). Consequentes da impossibilidade de renúncia ou transmissão não são as demais e irremovíveis características enxergadas. Contudo, é da técnica legislativa não exaurir conteúdo nem alcance de preceitos de ordem pública por causa da natural maturação do pensamento jurídico, que, por evoluir a ligeiros passos, diversos daqueloutros compreensível e insuperavelmente trôpegos do legislador, pode com eles deparar restrição ou aumento. Razão outra inexiste para justificar a ilimitabilidade da enunciação dos direitos personalíssimos no próprio art. 11. O exaurimento da lista de direitos intuídos pelo engenho humano arrisca a garantia sublime de proteção às plúrimas e vez outra insondáveis - porque múltiplas e defluentes da razão pura -, formas de manifestação da expressão pessoal, que, nem sempre, correspondem ao que possa responder pelo quod plerumque fit ${ }^{39}$.

Do art. 11 ainda se extrai aspecto outro cuja importância inspira exame também atento. Fixou-se, em frase final, a invalidade de qualquer limitação espontânea ao exercitamento de direitos personalíssimos. A objetividade da ressalva não se harmoniza com a simplicidade de conclusão daí tirada.

Os direitos aqui estudados são tão caros à ordem jurídica, os mais caros, que a eles e a bem deles se fez registrar, na própria lei, como a nenhum outro se fez, as características de início apontadas e atrás revistas. Ao se comandar a invalidade da restrição ao exercício de qualquer direito personalíssimo, embora emanada da voluntas do próprio e único titular, não se almejaria, porque contrária ao fluxo da própria ordem natural da vida e ao curso das coisas (sobretudo das relações econômicas que as permeiam), a limitação absoluta de seu exercício. A

em vida ou após o falecimento, nestes casos admitindo-se, inclusive, que, a lei torne um direito indisponível 'transmissível', como por exemplo, o direito de imagem, pelo menos no que diz respeito à sua defesa".

${ }^{39}$ No já referido Projeto de Lei $n^{\circ}$ 6.960/02, encontra-se proposta de alteração do art. 11 do Código vigorante em que, além da enunciação de direitos em rol ainda aberto, colacionam-se outras características além das três hoje ali vistas. O texto projetado foi acima transcrito, na nota 46. 
dicção do art. 11 dixit minus quam voluit. Ao titular de um direito de tal envergadura não se poderia, como exemplo, obstar a permissão de se deixar filmar ou, e também, de se deixar conhecer no interior de seu lar. O direito à própria imagem e o direito à privacidade aí exemplificantes, cotidianamente exemplificantes porque tal ou qual ocasião, além doutras, participa da incontornável fluência da vida de qualquer pessoa, não implicariam, à lei ou mesmo aos costumes, exercício capaz de vulnerar qualquer e caro aspecto ostentado pelos direitos personalíssimos. Mas de limitação voluntária se trata. O pungilista que se dispõe à eventual violação de sua inteireza somática, talvez menos que o fumante incontinente que a ela no cotidiano se expõe doutro e velado modo, vulnera, pelo exercício do direito à liberdade, direito personalíssimo diverso. Rediga-se que a liberdade é o primeiro e maior atributo que da vida deflui. Insondável e multiforme, orienta-se ao sabor das particulares volições e idiossincrasias, dos caracteres e recalques agregados pela personalidade psicossocial humana. A liberdade de consentir, para se ver retrato numa revista ou numa propaganda, para permitir a penetração alheia na privacidade, para permitir a própria comercialização de um produto do espírito (foto, livro etc.), ou sua simples exposição ou divulgação, impregna a marcha da vida para a qual se apresenta em sua imensurável dimensão.

O consentimento, ou voluntária limitação da vontade humana à disposição parcial dos direitos personalíssimos, é expressão sublime e insuperável da liberdade.

Entre as múltiplas características que ornamentam os direitos personalíssimos tem lugar a da disponibilidade relativa através da qual se explica o conteúdo da limitação voluntária ao exercício desses direitos.

A relatividade tem, aí, olhos na temperada interpretação não só da lei, mas das incontíveis e crescentes, embora vetustas, exigências de costumes e interesses privados, acima enxergados, para os quais o legislador não se tornaria míope.

Deveras, se os direitos personalíssimos não podem ser destacados da pessoa, e assim o é com sobra de razões, porque "fazem corpo com ela", como enfatizam Henri, Léon e Jean Mazeaud e François Chabas (1997, p.375), suas 
faculdades, algumas delas, podem ser cedidas (CIFUENTES, 1995, p.187). A fruição e a exploração de parte dessas virtudes ou faculdades não ofendem a preservação do direito de que emanam. E tal se revela, também, com a publicação consentida do retrato, da divulgação ou devassa da privacidade e da própria tolerância da ofensa à honra. $\mathrm{O}$ direito permanece intacto. Cedidas são, diversa e sempre temporariamente, suas potencialidades, no que consiste a faculdade máxima de disposição. É a exploração econômica das virtudes do direito que se permite, o right of publicy do ordenamento estadunidense. Distintas em conteúdo e alcance, e por isso ilícitas, se apresentariam, v.g., a contratação vitalícia de trabalho e a tolerância continuada à honra, a primeira, porque espezinharia o status libertatis; a segunda, porquanto aniquilaria um dos direitos mais estimados pela sociedade.

De tal modo, e conforme escrevemos alhures (JABUR, 2004, p.28-29), que o exemplificativo desnudamento da própria intimidade (Intimsphäre) - círculo de menor raio, mais restrito, que se embute na privacidade (Privatsphäre), esfera maior e concêntrica -, conquanto sórdido e, vez outra, vigoroso contribuinte da degenerescência da dignidade humana, não se insere, tecnicamente, na vedada limitação voluntária posta no caput do art. 11 da Lei Privada.

Deveras, a limitação inválida, e com sobra de motivos, é aquela que se tolhe do titular de um direito personalíssimo a fruição de (i) todas suas particulares e incessíveis potencialidades (ii) indeterminadamente.

A temporária e parcial cessão, graciosa ou onerosa, das virtudes contidas num direito personalíssimo não afronta 0 art. 11 do Código Civil. A exploração econômica de alguns direitos personalíssimos recebe até tratamento da lei, da maior à menor. A Constituição Federal assegura o direito de arena do qual desfruta o participante de obras "coletivas e à reprodução da imagem e voz humanas, inclusive nas atividades esportivas", como o atleta de futebol ou congênere (art. 5ํ, XXVIII, a). Aí se cuidou do direito à imagem, composto por qualquer forma sensível de manifestação da pessoa ${ }^{40}$. A exploração econômica é realçada pela alínea seguinte

40 Direito de arena não é direito moral do autor de obra intelectual. É componente do direito de imagem. A lei autoral anterior o contemplava. A atual não o faz. Dele também cuidam a Lei oㅡ 
trazida pelo mesmo inciso da Lei conforme a qual também se assegura proteção ao "direito de fiscalização do aproveitamento econômico das obras que criarem ou de que participarem aos criadores, aos intérpretes e às respectivas representações sindicais e associativa" (art. 50, XXVIII, b). A Lei de Direitos Autorais (Lei $\mathrm{n}^{\circ}$ 9.610/98) refere (art. 22) e trata, em capítulo autônomo (arts. 29 a 45) dos "direitos patrimoniais" do autor de obra intelectual. Decerto que os direitos de outra natureza considerou não apenas incessíveis: "Os direitos morais do autor de obra intelectual são inalienáveis e irrenunciáveis" (art. 27).

De maneira que a pedra fundamental na qual tem assento a ajustada intelecção da limitação expressa no art. 11 do Código Civil doméstico repousa no tipo e nas condições da limitação voluntária permitidos ao direito. Como já encarecemos (JABUR, 2000a, p.55), a temporária e parcial aquiescência para divulgar a imagem, penetrar a privacidade ou exibir as obras do espírito não traz ofensa à proibição da voluntária restrição vista no art. 11 da Lei Privada ${ }^{41}$.

Trato mais claro e consciencioso, na verdade exemplar, lê-se no art. $81^{\circ}$ do Código Civil português cuja rubrica é a "Limitação voluntária dos direitos da personalidade" debaixo da qual se registrou que "1. Toda a limitação voluntária aos exercício dos direitos da personalidade é nula, se for contrária aos princípios da ordem pública". O condicionamento da nulidade ao atentado aos princípios da ordem pública, que sintetizam o que compõe os valores sociopolíticos fundantes do Estado de Direito (que na moral também resgata elementos de integração), ostenta inexorável coerência com os efeitos da liberdade humana. Deveras, do direito personalíssimo não se poderá extrair produto, gracioso ou oneroso, em desconformidade com o invergável arrimo da ordem pública no qual se fixam os pilares da estrutura de qualquer Estado de Direito. É a partir da dignidade (valor supremo) que a ordem pública, conjugada por valores insuperáveis, é edificada. O

9.615/98 e seu Decreto regulamentador $n^{\circ}$ 2.574/98. A exclusão do direito de arena do rol dos direitos autorais foi sufragada por Plínio Cabral e por Silmara Juny A. Chinelato e Almeida (2002, p.10-11), como ela própria notícia.

${ }_{41}$ Assim também enunciou o Centro de Estudos Judiciários do Conselho da Justiça Federal (Enunciado $4^{\circ}$ ), ao enfatizar que sobredita e voluntária limitação não merece vedação, "desde que não seja permanente nem geral" (Enunciados aprovados na Jornada de Direito Civil ocorrida entre 11 a 13.09.2002, sob a coordenação cientificada o Ministro Ruy Rosado de Aguiar Junior). 
exercício ou o aproveitamento de faculdade personalíssima contrária a esse plexo de conteúdo essencial à manutenção das mínimas funções do Estado revela-se nulo. É nula, por exemplo, a utilização do nome, imagem ou privacidade para fraudar interesse público ou particular. Se o condicionamento à ofensa da ordem pública lido no Código português em nosso Código não se vê, sua ausência, por outro lado, não arreda, em qualquer ordenamento jurídico, a observância do que nela se compreende. Se entre os irmãos peninsulares a ordem pública é limite exclusivo ao exercício de direito personalíssimo, cá ele é apenas o mais importante óbice.

Da sensibilidade do legislador português também defluiu norma contida na segunda parte do art. $81^{\circ}$ da qual se retira que "2. A limitação voluntária, quando legal, é sempre revogável, ainda que com obrigação de indemnizar os prejuízos causados às legítimas expectativas da outra parte", de tal sorte que, em prestígio à liberdade da pessoa, a revogação de ato do qual tenha resultado o exercício do direito é legítima, mas sob a contrapartida indenizatória ${ }^{42}$.

\section{A CLÁUSUla GeRAL AOS ATENTAdOS DA PERSONALIDADE CONTIDA NOS ARTS. 12 E 21}

A cláusula geral inscrita no art. 11 do Código tem conteúdo distinto daqueloutras adiante vistas. É cláusula geral limitativa de direito, pelas razões antes postas. As firmadas nos arts. 12 e 21 seriam cláusulas gerais aos atentados a direito. A ratio essendi é a mesma, tutelar o livre desenvolvimento da personalidade, mas a finalidade, para cumprimento da proteção difere.

A lembrar a estrutura atribuída ao tratamento português, nossa codificação também cuidou de uma cláusula geral da personalidade endereçada aos atentados nele infundidos ${ }^{43}$, ideia que também se apresenta no ordenamento suíço ${ }^{44}$.

\footnotetext{
42 A indenização, anota Paulo Mota Pinto (2003, p.30), "não é condição da produção do efeito revogatório".

${ }^{43} \mathrm{O}$ art. $70^{\circ}$ do Código Civil português (1966) estabeleceu a "tutela geral da personalidade": "1. A lei protege os indivíduos contra qualquer ofensa ilícita ou ameaça de ofensa à sua personalidade física
} 
Modelar é a geral cláusula aos atentados a direitos personalíssimos lida no art. 16 do Código Civil francês ${ }^{45}$ : "A lei assegura a primazia da pessoa, proíbe todo atentado à sua dignidade e garante o respeito ao ser humano desde o começo de sua vida" ${ }^{46}$.

Cláusulas gerais são aquelas dotadas de vagueza, portadoras de termos genéricos e imprecisos, que atribuem ao intérprete aptidão de construir solução que se concilie com a diretriz ou o critério estabelecido na norma em que editada. $O$ legislador fixa o rumo, mas não apresenta o destino. Entrega a matéria-prima, porém deixa a manufatura ao talante do intérprete cônscio do conteúdo essencial da norma cuja extensão ou dimensão edificará. A consequência ou solução à fattispecie que impulsiona o exame da cláusula geral é tarefa exógena, fora da norma, cometida ao intérprete de olhos postos na adequada axiologia. Do magistrado, natural e ordinário aplicador dessa cláusula dinâmica, construída em obséquio à própria mobilidade do sistema no qual têm curso relações multifárias criadas pela riqueza do cotidiano, reclamar-se-á atento desvelo, já porque não se Ihe entrega uma carta-branca, mas uma carta na qual jaz elementar direção jurídica arrimada em critérios hígidos e aceitos como indefectíveis pela experiência e mentalidade jurídicas, já porquanto, e por consequência, o pétreo dever de fundamentação recrudesce ${ }^{47}$.

ou moral. 2. Independentemente da responsabilidade civil a que haja lugar, a pessoa ameaçada ou ofendida pode requerer as providências adequadas às circunstâncias do caso, com o fim de evitar a consumação da ameaça ou atenuar os efeitos da ofensa já cometida". $\mathrm{O}$ art. $26, \mathrm{n}^{\circ} 1$, da Constituição lusitana (1976), na linha dos modernos textos constitucionais ou fundamentais (Itália, art. 3o; Alemanha, art. $2^{\circ}$; Grécia, art. $5^{\circ}$ ), encarece a proteção "ao desenvolvimento da personalidade".

${ }^{44}$ A Lei Federal de 16.12.1983 (vigorante desde 1ํ.07.1985) introduziu sensível modificação no Código Civil suíço cujo art. 28 assim fixou: "1. Aquele que sofre um atentado à sua personalidade pode ajuizar ação para proteção contra todas as pessoas que dele participam. 2. Um atentado é ilícito, a menos que ele não seja justificado pelo consentimento da vítima, por um interesse preponderante privado ou público, ou pela lei".

45 Inserida pela Lei no 94-653 de 29.07.1994.

${ }^{46} \mathrm{~A}$ proteção genérica à personalidade já era, em França, construída a partir da expressão do art. 9ำ do Código Napoleão após alteração que nesse artigo se fez, em 17.07.1970 (Lei oㅜ 70-643), para preservar a "intimidade da vida privada". A doutrina aí já enxergava, em conciliação com os instrumentos de inibição deferidos à cautela do magistrado pelo art. 809 do Código de Processo Civil, meio de defesa "mesmo fora do domínio da vida privada". $O$ art. $9^{\circ}$, alínea $2^{\mathrm{a}}$, tornou-se superabundante" (MAZEAUD; et. al., p. 389, nota 16).

47 Diversa é a compreensão dos conceitos legais indeterminados em que a solução, já na lex, reclama a adequação do fato mediante subsunção. A imprecisão ou indeterminação, ao revés do que se enxerga nas cláusulas abertas (nas quais o alcance é vago, porque produzido pela valoração dos 
art. 21 do Código Civil fixa mais uma cláusula genérica posta à cessação ou reparação em virtude de atentados a direito autônomo conforme a qual ao juiz se defere, sem mais dizer nem a solução portanto fazer aportar, que as "providências necessárias para impedir ou fazer cessar ato contrário a esta norma”, tuteladora da privacidade, são autorizadas. Dela melhor se cuidará, à frente, quando oportunamente se examinar o direito ali protegido.

A postulação de uma cláusula geral aos direitos personalíssimos foi superiormente examinada por José Lamartine Corrêa de Oliveira e Francisco Ferreira Muniz em quem a enumeração ou tipificação de direitos dessa espécie, fragmentados ou não, era insatisfatória. Através de uma cláusula geral poder-se-ia "fornecer a base de uma jurisprudência coerente, mas suficientemente sensível para a solução das mais variadas hipóteses de lesão aos direitos de personalidade" (OLIVEIRA; MUNIZ, 1979).

Se os direitos especiais de personalidade são insuficientes quando divorciados de uma regra genérica e ajustável a qualquer hipótese de ameaça ou lesão, supérfluos não são, porque neles há de se concentrar a tutela recainte naquelas relações de vida que mais evidenciam atentados para os quais a especificidade da norma criada (a um direito personalíssimo próprio), sua riqueza e detalhamento, revelar-se-á seguramente proveitosa. Paulo Mota Pinto acentua que os especiais direitos personalíssimos se apresentam como "determinações do direito geral" ou "formas descentralizadas da tutela jurídica da personalidade". Deveras, e

critérios firmados na raiz da norma), confina-se ao conteúdo cujo ajustamento aos fatos se requer do intérprete. As cláusulas gerais evidenciam técnica diferenciada de legislação, como que fontes jurídicas impróprias. São também exemplos de cláusulas gerais, sempre fundadas na aplicação do direito concreto, as que concernem à observância do mandamento genérico da boa-fé (CC, arts. 113 e 422), maior e mais caro componente do tráfego jurídico e do fluxo das relações sociais, tão vetusto quando o próprio direito, e à aplicação da função social do contrato (CC, art. 421) e da propriedade (CF, art. 5o, XXIII). São exemplos de conceitos legais indeterminados aqueles postos nos arts. 329 (segundo o qual a prova de "motivo grave" impediente da realização do pagamento no lugar determinado autoriza o devedor a fazê-lo noutro, desde que ausente prejuízo ao credor; a regra foi incorporada, como tantas outras vistas no Código vigorante, pelo impulso da jurisprudência) e 478 do Código Civil (que faculta ao devedor a resolução do contrato se alterado o ambiente objetivo em que as partes contrataram por força de "acontecimentos extraordinários e imprevisíveis" suficientes a criar, a uma das partes, prestação "excessivamente onerosa, com extrema vantagem para a outra"). O preenchimento do conteúdo de cada expressão que acima se destacou mediante aspas é, vista a espécie concreta, precisar o conceito que a lei não trouxe. 
com esse autor português, "não é necessário recurso ao direito geral, que funciona, portanto, como ultima ratio, para o caso de insuficiência da tutela dispensada pelos direitos especiais" 48.

Evidente é que uma regra polimorfa em seu conteúdo e alcance prestiga a complexidade das relações jurídicas das quais múltiplos efeitos podem decorrer. Quando não se adjetiva, não se restringe, não se reduz o espectro de incidência do comando legal, mas se embute sua extensão na própria medida das concretas relações jurídicas. A cláusula geral protetiva das expressões personalíssimas é exigência da insondável capacidade humana de relacionamento, é produto da complexa e variante teia de resultados produzidos pelo fluxo da vida ${ }^{49}$.

As cláusulas gerais aos atentados a direitos personalíssimos são reflexo seguro do obséquio à dignidade da pessoa humana, valor supremo que dita e limita o alcance de todo e qualquer direito, norma ou princípio. A dignidade não tem gradação (CF, art. 1ํ, III). Inexiste indigno no tecido jurídico. É sobrenorma que conduz, como termômetro, a aplicação do direito. Pertence à razão pura, porque transcende, preexiste. Tal é a bússola, que ao seu operador indica o norte, qual é a dignidade, que ao intérprete mostra a trilha axiológica correta.

\footnotetext{
48 De sorte "que a autonomização de direitos especiais de personalidade, incidentes sobre particulares modos de ser da personalidade e com uma dogmática específica, mantém utilidade, não devendo reconduzir-se todos eles sempre a um único e geral direito" (PINTO, 2003, p. 16).

49 Convém novamente referir a reflexão de Paulo Mota Pinto conforme a qual "o 'direito geral de personalidade' pode, assim, como previsão ou 'norma de recolha', vir a abranger novas zonas de relevância da personalidade e proteger contra novas ofensas (pense-se apenas, por exemplo, nos complexos problemas hoje levantados pelas possibilidades de manipulação de material genético humano), não protegidas pelos direitos especiais. É, neste sentido, 'aberto' sincrónica e diacronicamente, permitindo a tutela de novos bens, e face a renovadas ameaças, sempre tendo como referente o respeito pela personalidade, quer numa perspectiva estática quer na sua dinâmica de realização e desenvolvimento: 'É, a um tempo, direito à pessoa-ser e à pessoa-devir, ou melhor, à pessoa-ser em devir, entidade não-estática mas dinâmica e com jus à sua 'liberdade de desenvolvimento"' (PINTO, 2003, p. 17; a transcrição aspada foi tirada pelo autor português de Orlando de Carvalho, 1981, p. 180).
} 


\section{LEGITIMAÇÃo ATIVA PARA A TUTELA GENÉRICA DA PERSONALIDADE}

O único parágrafo do art. 12 reafirma que a morte não ceifa todos os direitos da personalidade. A honra, por exemplo, não fenece, mas se imiscui, funde e se confunde com a própria honra dos sucessores do finado (ao menos com a deles). Essa a prima ratio da preceituação, quiçá entre outras de direito posto através das quais se pune a ofensa à honra do morto (CP, art. 138, $\S 2^{\circ}$; Lei ํㅡ 5.250/67, art. 24). Assim também o é com a imagem, que pela voz igualmente se revela, ou por qualquer meio sensível de identificação da pessoa ${ }^{50}$. O direito moral do autor também se perpetua com os sucessores ${ }^{51}$.

Por isso é bem posta a legitimação no parágrafo único do art. 12 em exame. Defere-se a iniciativa da tutela ao cônjuge supérstite e, sucessivamente, a qualquer parente em linha reta ${ }^{52}$ (genitores ou ancestrais, filhos ou descendentes), ou a colaterais até o quarto grau ${ }^{53}$. Todavia, não se a cometeu ao companheiro, a despeito do reconhecimento da união estável (CF, art. 226, § 3º), inclusive no texto da mesma Lei Privada (arts. 1.723 a 1.727). Mesma omissão legislativa se lê no único parágrafo do art. 20 do Código Civil, cujo atribuição legitimante é ainda mais restrita.

A improvável aptidão que, de pronto, teria o companheiro para afiançar sua condição não poderia ser óbice à extensão da legitimação. É aptidão cuja possibilidade, probabilidade ou certeza da respectiva prova pertence ao casuísmo. De mais a mais, é provável, porque conditio para a geração de efeitos pessoais e patrimoniais, que o companheiro ou companheira, por ocasião do óbito do outro ou da outra, prove sua qualidade e reclame perante o Judiciário os efeitos dela defluentes. De modo que, quer-nos assim parecer, somente no interstício entre a

\footnotetext{
50 "Toda expressão formal e sensível da personalidade de um homem é imagem para o direito" (MORAES, 1972).

${ }^{51}$ Conforme aqui já se anotou: Lei oํ 9.610/98, arts. 5ํㅡ, VIII, e, e 24, § 1ํ.

${ }^{52} \mathrm{CC}$, art. 1.591.

53 Embora inalterada a graduação da vocação hereditária do colateral, limitada ao quarto grau (CC/1916, art. 1.612; CC/2002, art. 1.839), a consideração ou existência da colateralidade ou transversalidade de parentesco foi reduzida do sexto para o quarto grau (CC/1916, art. 331; CC/2002, art. 1.592).
} 
morte do companheiro lesado na honra e o reconhecimento judicial da qualidade da pessoa cujo convívio foi pela morte do companheiro ceifado é que a dificuldade de prova sobreviria. Isso não obstaria que, em juízo de prudente e prévia valoração, nos mesmos autos em que se postule medida protetiva do direito personalíssimo, se investigue a legitimidade para a causa.

A omissão, contudo, não exclui ou impede, uma vez verificado atentado a direito personalíssimo do falecido, a provocação judicial de companheiro, porque inconciliável com a já sedimentada construção do sistema jurídico, que, na dignidade da pessoa deita assento (CF, art. 1ํㅡㄴ III). É que o reconhecimento da união com os requintes de estabilidade recolhidos pela lei (CC, art. 1.723) gera indisputáveis efeitos pessoais, entre eles o de "respeito e assistência" (CC, art. 1.724), que também são compostos, talvez entre outras manifestações, pela preservação da honra, imagem, privacidade ou direito moral de autor.

Não se examina apenas a legitimatio para postulação dos efeitos patrimoniais derivantes de eventual indenização motivada pelo ilícito à memória do morto em virtude do qual aos sucessores, mediante presunção legis tantum, e, a terceiros, mediante prova efetuada, atribui-se direito próprio de ação. Examina-se, também, a legitimação para as medidas preventivas ou interruptoras do dano que poderão ser invocadas (facere ou non facere) distantes do terreno último e odioso da condenação pecuniária.

Não se compraz com a própria incursão e qualificação jurídicas da figura do companheiro, que herdeiro do outro também o era (Lei ํㅡ 8.971/94, arts. $2^{\circ}$ e $3^{\circ}$ ) e o é (CC, arts. 1.790 e 1.830), privá-lo da tutela de direitos personalíssimos (honra ou a imagem, v.g.) que, com a morte, também se fundem e se confundem na personalidade jurídica do companheiro sobrevivente. O parágrafo único examinado, omisso no que diz à legitimidade do companheiro ou da companheira, antes de não se harmonizar com a sistemática atribuição de subjetivos direitos ao sobrevivente, colide com a natural e preciosa confusão de virtudes personalíssimas entre aqueles que, ex rigore juris, conviveram sob a estabilidade através da qual se afirma idônea 
e por isso legítima a tutela de qualquer medida sancionadora de lesão ou ofensa a direito também conectado à personalidade jurídica do morto ${ }^{54}$.

\section{DIREITO AO CORPO E AO CADÁVER HUMANOS}

Servindo-se do art. 30 do Anteprojeto de Orlando Gomes (1963), o art. 13 do Código Civil proíbe qualquer ato de disposição do corpo do qual decorra (a) diminuição permanente da inteireza somática ou (b) ofensa aos bons hábitos sociais. O texto de Orlando Gomes reproduziu, tal qual o Código vigorante, o art. 5ำ do Código Civil italiano ao qual o legislador nacional acresceu a ressalva inicial, permissora da disposição por exigência médica, e o parágrafo único, que encaminha o intérprete, noutra exceção, à legislação extravagante que se ocupa da (c) autorização e procedimentação para transplantes de partes humanas em que se compreendem a doação de sangue e seus de componentes e derivados ${ }^{55}$. Três são, portanto, as exceções (permissoras) à utilização destacada das partes humanas em benefício d'outrem inscritas no Código Civil: (i) disposição corporal exigida por médicos (eventual ato involuntário do paciente cuja vida corre risco), (ii) disposição corporal que não implique perene redução da integridade física ou contrarie os bons costumes (ato voluntário) e (iii) a disposição para o transplante ou a doação de partes humanas (ato voluntário).

Mas, tirante a primeira exceptio, que se afirma em homenagem à salvaguarda da vida humana, cuja decisão e técnica se revelam através do médico (CC, art. 13, primeira frase), as demais disposições voluntárias - ora aquela que, sem importar redução da inteireza somática ou violação dos bons hábitos sociais, pretenda a disposição do corpus (CC, art. 13, a contrario sensu), ora a que indica ao

54 O Projeto de Lei $n^{\circ}$ 6.960/02 pretende atribuir legitimação ao companheiro no único parágrafo do art. 12 em vigência.

${ }^{55}$ A Lei $n^{\circ} 9.434 / 97$, regulamentada pelo Decreto $n^{\circ} 2.268 / 97$, cuidou da "remoção de órgãos, tecidos e partes do corpo humano para fins de transplante e tratamento". A Lei $n^{\circ} 10.205 / 01$, regulamentou "o $\S 44^{\circ}$ do art. 199 da Constituição Federal, relativo à coleta, processamento, estocagem, distribuição e aplicação do sangue, seus componentes e derivados, estabelece o ordenamento institucional indispensável à execução adequada dessas atividade". 
intérprete a observância de lei especial para a efetuação de transplantes (CC, art. 13, único parágrafo) - subjazem, ambas, em leis extravagantes. O conteúdo fincado no único parágrafo do art. 13 do Código Civil declara a observância de lei própria, que tratou da "remoção de órgãos, tecidos e partes do corpo humano para fins de transplante e tratamento" (Lei no 9.434/97 e seu regulador Decreto 2.268/97). Não só a ela, contudo, há o intérprete do artigo em exame de prestar reverência. Conquanto da cabeça do analisado art. 13 nenhuma alusão à lex specialis se retire, a ela, precisamente à Lei № $10.205 / 0156$, haverá o intérprete de render atenção. É que a disposição do corpo humano não se materializa apenas na permissão da remoção de partes, órgãos ou tecidos para transplantes. Corporifica-se, de igual maneira, pelo fornecimento do sangue, do óvulo, do esperma ou até do cabelo exemplificativamente. A própria submissão do corpo à atividade e a esportes que sobre ele impliquem ofensa grave, que Ihe reduzam a inteireza, passa a identificar óbice à sua consecução.

A Lei oㅜ 10.211/01 ocupou-se, como também tratou a Lei o 9.434/97, da regulação da extensão do comando constitucional exibido no art. 199, § $4^{\circ}{ }^{57}$, cuja vedação a qualquer tipo de negociação econômica de partes ou produtos do corpo humano é expressa e inapelável. De tal modo que, em atendimento à diretriz constitucional vista, a Lei no 9.434/97 desenvolveu os rigores à transplantação de órgãos, tecidos e partes outras humanas, e a Lei № 10.211/01 normatizou o que pertinente é ao sangue humano a partir de sua coleta ${ }^{58}$. E dita coleta e posterior e necessário tratamento se embutem numa das hipóteses de disposição do corpo, decerto que se ausentes a redução e a vedação alinhadas no art. 13 do Código Civil.

56 Dois dias após a qual (21.03.2001) a Lei oㅜ 10.211 foi criada (23.03.2003) para modificar dispositivos da Lei ํㅜ 9.434/97.

${ }^{57} \mathrm{CF}$, art. 199 (caput. "A assistência à saúde é livre à iniciativa privada"), § 40: "A lei disporá sobre as condições e os requisitos que facilitem a [i] remoção de órgãos, tecidos ou substâncias humanas para fins de transplante, pesquisa e tratamento, bem como [ii] a coleta, processamento e transfusão de sangue e seus derivados, sendo vedado todo tipo de comercialização".

${ }^{58}$ A lei em apreço apenas cuidou do sangue, embora a Lei no 9.434/97 não tenha empregado tratamento a ele e a outros produtos do corpo humano consoante evidencia seu texto: Lei no 9.434/97, art. 10: "A disposição gratuita de tecidos, órgãos e partes do corpo humano, em vida ou post mortem, para fins de transplante e tratamento, é permitida na forma desta Lei. Parágrafo único. Para os efeitos desta Lei, não estão compreendidos entre os tecidos a que se refere este artigo o sangue, o esperma e o óvulo". 
A remoção de órgãos, tecidos e partes humanas vivas para transplante, nos termos e para os fins da lei de regência, depara - se permitidas, porque já depuradas pela regra da reserva da inteireza física posta a contrario sensu do que estabeleceu o caput do sobredito art. 13 - outras quatro exceções. Assim, (i) nãoproduzida diminuição permanente à integridade física nem ofensa aos bons costumes, a transplantação será lícita (ii) "quando se tratar de órgãos duplos, de partes de órgãos, tecidos ou partes do corpo cuja retirada não impeça o organismo do doador de continuar vivendo sem risco para a sua integridade e não represente grave comprometimento de suas aptidões vitais e saúde mental e não cause mutilação ou deformação inaceitável, e corresponda a uma necessidade terapêutica comprovadamente indispensável à pessoa receptora" (Lei no 9.434/97, art. $9^{\circ}$, § $3^{\circ}$ ), mas, só e tão-só, e graciosamente, rediga-se, quando não for para finalidade terapêutica, em benefício de (iii) "cônjuge ou parentes consanguíneos até o quarto grau, inclusive, na forma do $\S 40$ deste artigo, ou em qualquer outra pessoa, mediante autorização judicial, dispensada esta em relação à medula óssea" (Lei no 9.434/97, art. 9º , caput) ${ }^{59}$. De mais a mais, a doação para transplante (iv) "só poderá ser autorizada após a realização, no doador, de todos os testes de triagem para diagnóstico de infecção e infestação exigidos em normas regulamentares expedidas pelo Ministério da Saúde" (Lei n 9.434/97, art. 2ª , parágrafo único). Há outra exceção, endereçada às gestantes às quais é vedado "dispor de tecidos, órgãos ou partes de seu corpo vivo, exceto quando se tratar de doação de tecido para ser utilizado em transplante de medula óssea e o ato não oferecer risco à sua saúde ou ao feto" (Lei no 9.434/97, art. $9^{\circ}$, § $7^{\circ}$ ).

A comercialização de partes ou produtos do corpo humano, já posta na Constituição Federal (art. 199, § $4^{\circ}$ ) é apenada pela Lei oํ 9.434/97 com reclusão de três a oito anos e multa (art. 15). O mesmo tipo de pena, de um a seis anos, pesará sobre aquele que realizar transplante ou enxerto com partes humanas (art. 16),

\footnotetext{
${ }^{59}$ Lei $n^{\circ}$ 9.434/97, art. 90: "§ $4^{\circ} \mathrm{O}$ doador deverá autorizar, preferencialmente por escrito e diante de testemunhas, especificamente o tecido, órgão ou parte do corpo objeto da retirada. § $5^{\circ} \mathrm{A}$ doação poderá ser revogada pelo doador ou pelos responsáveis legais a qualquer momento antes de sua concretização."
} 
como também àquele que recolhê-las, transportá-las, guardá-las ou distribuí-las (art. 17), a despeito de obtidas em desacordo com a lei de regência ${ }^{60-61}$.

Mas não apenas sobre as partes vivas ou os produtos e subprodutos extraíveis do corpo humano a tutela legislativa repousa.

O corpo humano recebe proteção vivo ou morto ${ }^{62}$. Vistas aquelas que the tutelam a existência, outras há, de semelhante apreço à dignidade humana, recaintes sobre o corpo sem vida. É ausente o tratamento no Código Civil, à exceção fixada do que se lê em seu art. 14, que cuidou de um aspecto da destinação do cadáver. Entretanto, outros aspectos existem, de sorte a ter faltado legislar, sistematicamente, para a proteção ao defunto. Há dispositivos, adiante vistos, espraiados no conjunto legislativo e que, à vista da edição de Capítulo autônomo e próprio na Parte Geral do Código Civil, terreno adequado para tratamento, ali deveriam se apresentar mediante síntese protetiva suficiente ao

\footnotetext{
60 Mesma e restritiva preceituação se contém no Decreto 3.390/01, art. 2º, II a V.

61 A Lei no 94-653 de 26.07.1994 estabeleceu, em França, expressiva proteção do corpo humano conforme apurada redação que forneceu ao art. 16 do Código Civil. Ao lhe garantir o respeito de todos, consagrou-o inviolável e, tal qual "seus elementos e produtos", considerou-o insuscetível de "um direito patrimonial (CC, art. 16-1). Ao magistrado cometeu todas as medidas "próprias para impedir ou fazer cessar um atentado ilícito ao corpo humano ou em virtude de ato censuráveis sobre seus elementos ou produtos" (CC, art. 16-2). À prescrição atribuída ao art. 16-3 do Código Civil francês, pela Lei no 99-641 de 27.07.1999, assemelha-se aquela vista no caput do examinado art. 13 do Código brasileiro: "Não se produzirá atentado à integridade do corpo humano senão em caso de necessidade médica em benefício da pessoa". E fixa que o consentimento do paciente deverá ser "colhido preferivelmente fora da hipótese em que seu estado inspire necessária intervenção terapêutica à qual ele não pode consentir". O rigor dos comandos integrados pela Lei francesa de 1994 se apresenta mais evidente através da redação do art. 16-4 do Código Napoleão segundo a qual "toda prática eugênica tendente à organização da seleção das pessoas é proibida". Tirantes as pesquisas para prevenção e tratamento de doenças genéticas, "nenhuma transformação pode ser feita nos caracteres genéticos com o propósito de modificar a descendência da pessoa". Nulas são as convenções que ao corpo humano ou a seus produtos ou elementos conferem valor patrimonial (CC, art. 16-5), como também aquelas que digam à procriação ou à gestação por conta de terceiro (CC, art. 16-7). Vedou-se, decerto, qualquer remuneração em contrapartida a experimentações sobre a pessoa ou em virtude do que seu corpo produza (CC, art. 16-6). Doador e donatário autorizados não poderão conhecer a recíproca identidade, senão seus médicos, em caso de necessidade terapêutica, poderão ter acesso a informações que permitam a identificação (CC, art. 16-8). Remarcou-se que todas essas disposições são de ordem pública (CC, art. 16-9).

62 Não escapou a Henri, Jean e Léon Mazeaud e François Chabas (1997, p.378) a magnitude do resguardo do corpo humano cuja proteção "aparece como uma das prerrogativas essenciais do homem: direito à vida, à saúde. O direito se prolonga mesmo após a morte: direito do indivíduo ao respeito de seu cadáver".
} 
respeito do corpo humano morto, também não deslembrado pelo direito penal ( $\mathrm{CP}$, arts. 211-2; LCP, art. 67).

De modo que, além das duas exceções à restrição do uso do corpo ou de suas partes oportunizadas durante a vida do titular pelo art. 13 do Código Civil, cujo comando repontencializou aquelas hipóteses excepcionais firmadas em leis ordinárias, uma única outra é apresentada no art. 14 da Lei Privada, que, ex vi da manifestada aquiescência em vida, produzirá efeitos causa mortis. Fundada na solidariedade, tal qual se funda a exceptio do parágrafo único do artigo anterior, permite-se legar o corpus ou suas partes isoladas com propósito filantrópico, do que se afasta, sempre e sempre, qualquer ato de mercancia ${ }^{63}$. A liberdade recondutora do estado anterior é novamente prestigiada pelo parágrafo único do art. 14, que também homenageia a ressalva contida na última frase do caput do art. 11 do mesmo Código ${ }^{64}$. No texto do art. 14, extraído do art. 31 do Anteprojeto de Orlando Gomes, inseriu-se o propósito científico ou altruístico como motivações únicas para a cessão post mortem. A permissão legal, no texto do professor baiano, vinha encimada pela rubrica "Disposição do Cadáver". E assim se deve recebê-la. A Lei no 8.501/92 preocupou-se com o regramento do cadáver não-reclamado cujo uso permitiu "para fins de ensino e pesquisa" (art. $\left.1^{\circ}\right)^{65}$.

O cadáver não perde, independentemente da religiosidade do defunto ou da fé de seus sucessores, a qualidade de inviolável. A morte não liberta o corpus da dignidade. O corpo humano, mesmo após o fenecimento da vida e a despeito da res

\footnotetext{
${ }^{63}$ Adriano de Cupis (1961, p.93-94) acentua que o direito à destinação do cadáver é senão uma transformação do elemento corpóreo da própria pessoa, que se sobrepõe à vontade dos parentes. Se o dono do corpo vivo pode determinar a destinação a um instituto científico, os parentes podem apenas determinar o modo e a forma do destino normal do cadáver, "que consiste em ser dado à paz de sepultura segundo as formas admitidas pelo ordenamento jurídico".

${ }^{64}$ Maria Helena Diniz (2004, p.126) destaca aí, como nítida, "a consagração do princípio do consenso afirmativo [...]".

${ }^{65}$ A destinação ao estudo pressupõe a não-reclamação do corpo às autoridades públicas pelo prazo de trinta dias (art. $2^{\circ}$ ), desde que identificado, embora sem informações de endereços de parentes ou responsáveis legais (art. 3o, II), hipótese na qual a autoridade competente "fará publicar, nos principais jornais da cidade, a título de utilidade pública, pelo menos dez dias, a notícia do falecimento" (art. $3^{\circ}, \S 1^{\circ}$ ). O encaminhamento para fins de estudo do corpo suspeito de morte criminosa é vedado (art. $3^{\circ}, \S 3^{\circ}$ ). A possibilitada destinação do cadáver "sem qualquer documentação" inscrita no art. $3^{\circ}, \mathrm{l}$, dessa norma foi revogada, porque com ela incompatível (LINDB, art. $2^{\circ}, \S 1^{\circ}$ ), pelo art. $6^{\circ}$ da Lei $n^{\circ} 9.434 / 97$, conforme o qual "é vedada a remoção post mortem de tecidos, órgãos ou partes do corpo de pessoas não identificadas".
} 
que passa a identificá-lo, conserva importância jurídica, motivo por que recebe a correlata proteção penal ${ }^{66}$ e civil. $\mathrm{O}$ direito ao cadáver (rectius, à destinação do cadáver) encontra escólio na lei e nos costumes informados pelos sentimentos de compaixão e devoção que se devem ao defunto, ora porque afirmativamente manifestado em vida, ora porquanto protegido pela própria omissão à destinação específica, que assume índole de recusa a propósito diverso daquele que, pela tradição ou pelos usos em família ou comunidade, se revela ordinário.

Por tudo, o aproveitamento do corpo morto para tal ou qual propósito altruístico dependerá sempre da manifestação do titular ou, silente, dos familiares nos estreitos lindes da lei, que reclama a autorização "do cônjuge ou parente, maior de idade, obedecida a linha sucessória, reta ou colateral, até o segundo grau inclusive, firmada em documento subscrito por duas testemunhas presentes à verificação da morte" (Lei n 9.434/97, art. $4^{\circ}$, caput) ${ }^{67}$.

A recusa à doação post mortem, cuja validação antes se condicionava ao registro da negação em carteira de identidade civil ou carteira nacional de habilitação, assim disposta pelo art. $4^{\circ} \stackrel{\text { }}{\S} 1^{\circ}$, da Lei $n^{\circ} 9.434 / 97^{68}$, foi revogada pela Lei $n$ ํ 10.211/01. E com sobra de razões. A regulação da liberdade humana, prima ratio do direito, não se compraz com a edificação de regras que da ausência de vontade retiram consequências que ao titular da omissão são desfavoráveis ou, pelo menos, diversas daquelas por ele aguardadas em atenção ao curso ordinário da vida. Quanto mais e, a fortiori, no que concerne ao uso do corpo humano cujo caráter sacrossanto é perene.

Não só por isso, a cremação do corpo morto também há de se fundar em ato inequívoco de vontade, não aquele tácito (que exterioriza o consensus de modo

\footnotetext{
66 Destruição, subtração e ocultação de cadáver são condutas penas típicas, assim como o vilipêndio (CP, arts. 211 e 212). A inumação e a exumação desautorizadas também sofrem apenamento (LCP, art. 67).

67 O Código Civil da Província canadense de Quebec estabelece que "na ausência de vontades conhecidas ou presumidas do defunto, a retirada por ser efetuada com o consentimento da pessoa que podia ou teria podido consentir aos cuidados" (art. 44).

${ }^{68}$ Cujo texto era assim lavrado: "A expressão 'não-doador de órgãos e tecidos' deverá ser gravada, de forma indelével e inviolável, na Carteira de Identidade Civil e na Carteira Nacional de Habilitação da pessoa que optar por essa condição."
} 
indireto), mas expresso (que expele o querer de maneira direta e indisputável) ${ }^{69}$. De tal modo, e como já escrevemos (JABUR, 2000, p.176b), que a cremação também exige firme declaração unilateral de vontade. A exemplo do testamento, merece validade, ainda que sem as formalidades que no último deitam substância. $O$ art. 77 , $\S 2^{\circ}$, da Lei ํo 6.015/73, ao tempo em que se ocupa do rigor para o sepultamento, fornece clara dicção proibitória da cremação desautorizada: "A cremação de cadáver somente será feita daquele que houver manifestado a vontade de ser incinerado ou no interesse da saúde pública e se o atestado de óbito houver sido firmado por dois médicos ou por um médico legista e, no caso de morte violenta, depois de autorizada pela autoridade judiciária".

Não há dispositivo(s) em sistema legislativo civil único destinado ao apreço pelo cadáver. Dele se tratou para finalidade de ensino ou pesquisa científica, quando desprezado (Lei no 8.501/92); para retirada de tecidos, órgãos e partes do corpo para transplantes ou finalidade terapêutica, dependentes de autorização familiar específica e sucessiva, excluído o companheiro (Lei oํ 9.434/97, art. 4ํㅜำ; para encarecer a obrigatória e condigna recomposição do corpo morto vulnerado para uma das finalidades atrás aludidas (Lei ํㅜ 9.434/97, art. 8ํ, art. 21 do Decreto no 2.268/97, que a regulamentou) ${ }^{71}$; para tipificar crimes pela inobservância de uma ou outra rigorosa procedimentação (Lei oํ 9.434/97, arts. 14 e 19) ) $^{72}$, além do vetusto apenamento penal fixado para a destruição, subtração, ocultação e vilipêndio do

\footnotetext{
${ }^{69}$ Merece referência a produção do consentimento lida no art. $340^{\circ}$ do Código Civil português.

70 "Art. 4․ A retirada de tecidos, órgãos e partes do corpo de pessoas falecidas para transplantes ou outra finalidade terapêutica, dependerá da autorização do cônjuge ou parente, maior de idade, obedecida a linha sucessória, reta ou colateral, até o segundo grau inclusive, firmada em documento subscrito por duas testemunhas presentes à verificação da morte."

71 "Art. $8^{\circ}$. Após a retirada de tecidos, órgãos e partes, o cadáver será imediatamente necropsiado, se verificada a hipótese do parágrafo único do art. $7^{\circ}$, e, em qualquer caso, condignamente recomposto para ser entregue, em seguida, aos parentes do morto ou seus responsáveis legais para sepultamento." [...] "Art. 21. Efetuada a retirada, o cadáver será condignamente recomposto, de modo a recuperar, tanto quanto possível, sua aparência anterior, com cobertura das regiões com ausência de pele e enchimento, com material adequado, das cavidades resultantes da ablação."

72 "Art. 14. Remover tecidos, órgãos ou partes do corpo de pessoa ou cadáver, em desacordo com as disposições desta Lei: Pena - reclusão, de dois a seis anos, e multa, de 100 a 360 dias-multa. § 1.ำ Se o crime é cometido mediante paga ou promessa de recompensa ou por outro motivo torpe: Pena reclusão, de três a oito anos, e multa, de 100 a 150 dias-multa. [...]" [...] "Art. 19. Deixar de recompor cadáver, devolvendo-lhe aspecto condigno, para sepultamento ou deixar de entregar ou retardar sua entrega aos familiares ou interessados: Pena - detenção, de seis meses a dois anos."
} 
defunto (CP, arts. 211-2) ou, sob as luzes da contravenção penal, para a inumação ou exumação sem autorização própria (LCP, art. 67). O preceito legislativo para regular a autorização à retirada de órgãos e partes do morto é apenas existente para "cadáver de pessoas incapazes" e dependerá da anuência "expressa de ambos os pais, se vivos, ou de quem lhes detinha, ao tempo da morte, o pátrio poder, a guarda judicial, a tutela ou curatela" (Decreto $n^{\circ} 2.268 / 97$, art. $\left.19, \S 4^{\circ}\right)^{73}$.

O espraiamento de dispositivos civis assecuratórios do direito ao cadáver revelar-se-ia razão suficiente para que o novo Código incorporasse preceituação aglutinadora ou indicativa do tratamento ao corpo humano morto, senão por lembrança do art. 32 do Anteprojeto de Orlando Gomes (redigido sob o nomen "Direito ao Cadáver" ${ }^{74}$ ), por imposição preditada pela dignidade humana sob cujo influxo as direitos personalíssimos têm assento e consagração.

Deveras, além da tíbia proteção desenvolvida no art. 14 do Código Civil, porquanto particularizada sem pretextar tratamento amplo ao cadáver e sua destinação, a necessidade de reformulação de seu conteúdo se faz verdadeira para passar a tratar o que ali se pôs apenas como agregada ou secundária disposição, após proteção criada para, pelo menos, regular (i) o local de sepultamento, sua modificação ou violação, (ii) a utilização do corpo, de suas partes ou restos e (iii) a qualidade da anuência exigida para o que concernente seja à disposição ou ao direito sobre o corpo.

Decerto que a atribuição de legitimidade ao companheiro, consequente ao sistema atual de direito posto, merece registro, embora compreensivelmente ausente do texto sugerido pelo saudoso professor baiano.

O Código Civil renova o apreço ao corpo humano e o conseguinte valor da liberdade pessoal conforme dispôs, no art. 15, que "ninguém pode ser constrangido a submeter-se, com risco de vida, a tratamento médico ou a intervenção cirúrgica" (sic). O risco aí mencionado é de morte, porque é a vida que se ceifaria, não a

${ }_{73}^{73}$ É Decreto regulamentador da Lei no 9.434/97.

74 "Art. 32. Direito ao Cadáver - O lugar em que deve ser sepultado o cadáver, sua remoção, a autópsia e quaisquer providências que digam respeito aos despojos morais serão decididos pelo cônjuge sobrevivente, ou na falta deste, pelos parentes, conforme a ordem de vocação hereditária. Parágrafo único. Não se compreendem nessas prerrogativas os atos de disposição do cadáver." 
morte, que pode se avizinhar. A norma do art. 15 presta nova homenagem à recusa à limitação voluntária do exercício de direito personalíssimo (CC, art. 11, última frase). O texto decorre do aproveitamento do art. 33 do Anteprojeto de Orlando Gomes ao qual se acresceu a expressão "risco de vida". Ainda que à morte o risco se apresente concernente, o acréscimo é supérfluo tal como posto. A liberdade humana de recusa se endereça a qualquer tratamento médico ou intervenção cirúrgica. O risco de morte, ao revés, seria acréscimo de relevo se excepcionasse a liberdade do indivíduo (permitindo assim a intervenção), não para reencarecê-la. De qualquer sorte, a adequada mens legis do art. 15 parece ser aquela preocupada em revigorar o apreço pela liberdade humana do enfermo cujo constrangimento à aceitação de tratamento médico ou cirúrgico não poderá ocorrer mesmo com risco de morte.

Preservou-se a liberdade negativa do doente ${ }^{75}$.

\section{DIREITO AO NOME}

Eram sete os artigos dedicados à tutela do nome no Anteprojeto de Orlando Gomes (Capítulo IV, arts. 38 a 44), interessantemente cuidados fora do Capítulo III, criado ao trato dos direito da personalidade (arts. 29 a 37). Deles, o Código Civil recolheu três, convolados quatro ${ }^{76}$. O Anteprojeto serviu-se de parte dos arts. $6^{0} \mathrm{e}$ 9 do Código Civil italiano para, influenciada a redação do Código Civil em vigor, construir os arts. 16 e 19 respectivamente ${ }^{77}$.

\footnotetext{
75 Sobre o conceito de liberdade negativa e sua distinção entre liberdade positiva, Paulo Mota Pinto (2003, p.21) refere diversos autores que dele se ocuparam no trato da filosofia.

${ }^{76} \mathrm{O}$ art. 16 corresponde ao caput do art. 38 e o art. 17, ao caput do art. 42 cujo único parágrafo identifica 0 art. 18 do Código Civil. A redação é fiel em todos. O art. 19 sintetiza o art. 43 daquele texto no qual, todavia, não se acentuou a proteção condicionada ao uso pseudônimo para "atividades lícitas". Conquanto defluente da interpretação consonante à ordem pública, o realce não é supérfluo.

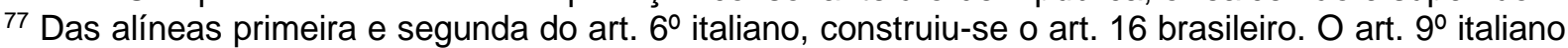
difere do nosso art. 19 porque ali, rediga-se, se reclamou a importância do pseudônimo, sobre o que silenciou nosso Código.
} 
O direito à identidade pessoal, no qual se arrima a proteção aos elementos que a exteriorizam (sobrenome ou patronímico e prenome, que compõem a noção lata de nome, assim dita pelo art. 16), é uma das mais caras expressões da personalidade, que, no contexto das relações sociais, se revela pelo nome ao qual se conectam, no campo dos reflexos, a despeito da autonomia de conteúdo, a honra e a imagem. Atrelam-se para compor a impressão pessoal e social da personalidade 78. Distinguem-se porque se compõem de elementos independentes, superadas, há lustros, doutrinas que embutiam a imagem nos atribuídos da honra ou do nome ${ }^{79}$.

É o nome, a plenas luzes, "um quid imaterial, meio de realização do bem identidade, intimamente ligado portanto à pessoa" (PINTO, 1979, p. 21) ${ }^{80}$. Os direitos personalíssimos, salvante aqueles que se ocupam da preservação da vida e da integridade física, não se evidenciariam senão através do apreço e respeito ao nome. Mesmo a asseguração da vida e do que dela deflui, sem bem vista, ao nome se conecta, porque a condução e a marcha da vida pretextam o conhecimento da identidade pessoal sem a qual as relações sociais, indiferente a importância, não se aperfeiçoam. O nome revela a existência da pessoa, que produz a personalidade.

$\mathrm{O}$ art. 16 do Código brasileiro, que endereçou proteção ao direito à identidade pessoal, evidencia preocupação com a extensão protetiva ali posta (ao prenome e ao sobrenome ou nome). $\mathrm{O}$ direito ao prenome é consectário do direito à identidade, mas dele difere porque é agregação posterior ao surgimento da pessoa. A atribuição do prenome, ao sabor das volições familiares e posterior ao nascimento com vida, é signo ou elemento pessoal e social de conhecimento que deriva da necessidade de identificação da pessoa. É, numa expressão, direito consequente à diferenciação pessoal que também se projeta, como todos os personalíssimos

\footnotetext{
78 Deveras, além da textura morfológica, da voz e dos gestos conectados à pessoa, a moderna doutrina contempla a bipartição do jus imaginis através da imagem-retrato, em que se embute a expressão corporal do fenômeno humano, e a imagem-atributo na qual se revelam as (boas ou más) características pessoais. As boas ou más revelações, contidas na consideração social da pessoa, corporificam uma das vertentes do direito à imagem, que, portanto, refere, ainda que de viés, mas necessariamente, o nome e, se malposta a alusão, a honra atingirá. É sensível a relação, embora assentes o conteúdo e a independência jurídicos de cada um desses direitos.

${ }^{79}$ San Tiago Dantas (1979, p. 197), na última década de quarenta, ensinava que através do nome se identifica a personalidade.

80 É laureada a monografia do saudoso Rubens Limongi França (1958).
} 
direitos, sob o influxo da dignidade humana. Propriamente personalíssimo é o direito à identificação pessoal, à ascendência, ao nome, ou nome de família, ou ao sobrenome ou patronímico, porque inato, sem vínculo com a atribuição em registro civil, que o dá a conhecer, tão-só. O prenome, conquanto posterior e fundamental, é correlativo necessário do nome porque, tal a existência da personalidade que decorre do nascimento com vida, qual a exteriorização do patronímico, que supõe um primeiro e comum elemento ou sinal ao qual deve obrigatória conexão ${ }^{81}$. A Lei de Registros Públicos acolhera o critério reproduzido pelo Código Civil. Diferenciou nome do pronome ${ }^{82}$.

É indistinta, entretanto, e assim deve ser compreendida através do art. 16, a proteção que se fornece ao nome e ao prenome (e também ao pseudônimo, adiante comentada). A correta e lícita alusão e utilização do patronímico e do prenome de todos pode exigir o titular mal ou desautorizadamente nominado. O sinal de identificação pessoal e social, que bem se revela pelo nome e seu agregado prenome, deve ser conhecido e mencionado tal como é herdado o primeiro e é concebido o segundo. Declarações, registros e arquivos de natureza pública ou particular devem atenção à correta grafia e ao lícito uso de qualquer componente da identidade pessoal.

A investigação de paternidade ou maternidade, cujo direito de ação judicial não prescreve porque preso à manifestação de um substancial direito que não cessa de produzir seus efeitos (mesmo além-morte), é manifestação por excelência do direito à ancestralidade (CC, art. 1.616) e de tudo o que lhe é conseguinte (CC, art. 1.824 a $1.828, v . g$.).

$\mathrm{O}$ art. 17 do Código Civil tutela a honra diretamente, e o nome obliquamente. O nele se pretendeu evitar foi a lesão à honra objetiva, ou, como ali se escreveu, "ao desprezo público" que a identifica. O animus nocendi é desprezado ("ainda quando não haja intenção difamatória"). Ainda que desnecessária a vontade de alçar o nome

$81 \mathrm{O}$ art. 54, 4⿳⺈), da Lei $n^{\circ}$ 6.015/73, decerto assim reclama.

82 Ao nome, como atributo de família, aludiu, v.g., nos arts. $\left.54,4^{\circ}\right), 7^{\circ}$ ), $\left.8^{\circ}\right)$ e $\left.9^{\circ}\right), 55,1^{\underline{a}}$ parte, 59,60 , $70,80,3^{\circ}$ ) e $\left.\left.5^{\circ}\right), 90,2^{\circ}\right)$ e $\left.92,2^{\circ}\right)$. O prenome referiu, v.g., nos arts. $54,55,58,63,70,80,3^{\circ}$ ) e $5^{\circ}$ ), $\left.90,2^{\circ}\right)$ e $\left.92,2^{\circ}\right)$. 
ao "desprezo público", e portanto vulnerar a honra, da qual cuidou o artigo, a difamação não é conduta exclusiva da lesão à honra. É uma entre três modalidades de a enodoar consoante informam os tipos penais construídos (CP, arts. 138 a 14; Lei $n^{\circ}$ 5.250/67, arts. 20 a 22, v.g.) e a doutrina que em torno deles se ergueu. A difamação diz com a divulgação de fato, falso ou verdadeiro, que alcança a consideração social ou reputação do difamado. Através da calúnia, malfere-se ainda mais o apreço social, porque o fato imputado ao caluniado é penalmente sancionado. Diversa é a configuração da injúria por meio da qual se apresenta juízo demeritório ou depreciador do ofendido, pouco importando a divulgação social para configuração do ilícito, que no sentimento de honorabilidade pessoal do injuriado centra sua ratio. Em verdade, a exposição pública do nome, compreendida como o social abalo da honra - por isso dela cuidou do artigo examinado — se apresenta já pela difamação, já pela calúnia. Melhor, porque genérica e e então abrangente, revela-se a proteção lida no art. $72^{\circ}$ do Código Civil português cuja primeira alínea defere ao titular, além do direito de "usar o nome, completo e abreviado", a faculdade de "opor-se a quem outrem o use ilicitamente para sua identificação ou outros fins".

Embora indisputável a distinção entre honra e nome e o que numa e noutro se contém - e sem se adentrar no exame do art. 20, à frente visto - o legislador da codificação brasileira registrou o resguardo da honra através da alusão ao nome, por influência do Anteprojeto brasileiro de 1963 e do Codice Civile. Se a condicionante implícita da proteção do nome é a exposição ao escárnio público, doutro direito, senão da honra, não cuida o art. 17.

O art. 18 trata, ao revés, de autêntica asseguração do direito ao nome cuja melhor dicção consideraria não apenas seu desautorizado uso em propagandas comerciais, mas para qualquer finalidade promocional, comercial ou institucional. As propagandas institucionais, que enaltecem o propagador e não o produto ou serviço por ele inserido no mercado, podem ou não ter indireto apelo à marca ou ao nome do divulgador e, mesmo quando difundidas por entidade filantrópica, evidenciam uso que, a despeito da superior finalidade, pode não consultar ao desejo de exposição 
do titular nominado. Melhor, reescreva-se, também por essa suficiente razão, a posição do legislador português, que se serviu de conceito legal indeterminado no art. $72^{\circ}$, conforme aqui se assinalou dois parágrafo acima ${ }^{83}$, cujo conteúdo, mediante subsunção, haverá de ser investigado e preenchido de olhos postos na aequitas. Ao magistrado, é melhor, que se atribua o juízo do que se lhe pareça inconciliável, e portanto ilícito, com o conjunto de valores que suportam a estrutura jurídica, com as regras morais ou com aqueloutras que se revelam pelos hábitos incorporados no âmago social.

De conformidade com o art. 19 do Código Civil, o nome adotado para o desempenho de alguma atividade em virtude da qual alguém se torna também conhecido mereceu atenção do legislador, que a esse suposto nome atribuiu a mesma proteção reconhecida ao verdadeiro nome. O Código não acresceu elemento qualificador da pseudonímia para protegê-la tal como protege o nome, diversamente do legislador italiano, que deferiu a tutela apenas ao pseudônimo "que tenha adquirido a importância do nome" (art. $6^{\circ}$ ) cuja depuração também se atrela à indeterminação de conceito. O codificador português, aparentemente mais severo, deferiu proteção ao pseudônimo "quando tenha notoriedade" (art. 74\%). Aparentemente, porquanto a importância idêntica à do nome inserida pelo Código italiano há de ser notória, porque notório é o nome. De tal sorte que, apesar da ênfase maior do Código lusitano, num e noutro documento se reclamou a autêntica projeção social do falso (pseudo) nome (ônimo). Nosso Código assim não exigiu, mas, quiçá, ao sabor da ciência jurídica, se dirá que, aí também, dixit minus quam voluit.

${ }^{83} \mathrm{O}$ titular pode "[...] opôr-se a que outrem o use ilicitamente para sua identificação ou outros fins" (1 ${ }^{\text {a }}$ alínea). 


\section{DIREITO À IMAGEM}

A tutela do direito à própria imagem, que não se confina na expressão ou exposição plástica do corpus mechanicum, mas se exprime pela projeção de qualquer forma perceptível de identificação física ou perceptível da pessoa, recebeu tratamento civil condicionado à lesão da honra ou ao propósito lucrativo do divulgador desautorizado. $\mathrm{O}$ art. 20 do Código Civil amealhou parte das prescrições contidas no art. 36 do Anteprojeto de Orlando Gomes ${ }^{84}$, que se abeberou, sem bem mensurar a construção gramatical e a expressão valorativa nele postas, no art. 10 do Codice Civile ${ }^{85-86}$.

As ressalvas fixadas na frase inaugural do art. 20, conquanto dotadas de imprecisão, apresentam-se, em sua largueza, plenas de justificativas. A "administração da justiça" converge o que necessário for à condução pronta e organizada, eficiente e célere dos trabalhos cujo propósito, dentro ou fora do Judiciário, se enderecem ao obséquio e à confirmação do Estado de Direito. A "divulgação de escritos" e a "publicação" da imagem regradas no artigo examinado, quando feitas por determinação judicial ou até legal, em processo penal ou civil, em querela pública ou privada, correspondem a exemplos de vulneração autorizada de direitos personalíssimos. A busca e apreensão e o vasculho daí fluente é cotidiana exceção. À "manutenção da ordem pública" - que aposto da "administração da justiça" aí não seria - fundem-se princípios, consoante atrás já reflexionamos, que ajuntam valores sociopolíticos fundantes do Estado de Direito, que na aplicação da

84 "Art. 36. Reprodução da Imagem - A publicação, a exposição ou utilização não autorizada da imagem de uma pessoa podem ser proibidas a seu requerimento, sem prejuízo da indenização a que fizer jus pelos danos sofridos. $\S 1$ ํํ $\mathrm{A}$ proibição só se justifica se da reprodução resultar atentado à honra, à boa fama ou à respeitabilidade da pessoa. $\S 2^{\circ}$ Os direito relativos à reprodução da imagem podem ser exercidos pelo cônjuge ou pelos filhos, se estiver morta ou ausente a pessoa."

85 "Art. 10. Toda vez que a imagem de uma pessoa ou de seus genitores, do cônjuge ou dos filhos seja exposta ou publicada fora dos casos em que a exposição ou a publicação é consentida pela lei, ou então com prejuízo ao decoro ou à reputação da mesma pessoa ou de seus parentes, a autoridade judiciária, a pedido do interessado, poder determinar que cesse o abuso, sem prejuízo da indenização por danos."

${ }^{86}$ Do direito à própria imagem, notadamente caro aos direitos personalíssimos, porquanto aquele que entre tais e sublimes direitos se revela vulnerado com freqüência na moderna sociedade e através dos impulsos vigorosos da mídia, tratamos em Limites ao direito à própria imagem no novo Código Civil, in Questões Controvertidas no novo Código Civil, ob. cit., p. 11-44. 
Justiça tem seu maior e inexorável comprometimento. A ordem pública é círculo concêntrico no qual jaz, como primeira razão, a produção da Justiça e a estabilização de seus indefectíveis cânones. Dessa pública ordem a que todos hão de aceder não se distanciam os componentes fundantes da moral, porque da construção do direito posto e do sistema que o compreende nunca se apartariam os hábitos salutares, amadurecidos, consolidados e incorporados ao centro de existência social da qual o legislador inça o edifício jurídico. A ordem pública tem como primordial fim a "administração da justiça", mas com ela não se confunde, posto multímoda. A exposição "da imagem de uma pessoa" (CC, art. 20) em ensaio ou prática de ato de vandalismo, terrorismo ou subversão a um dos princípios constitutivos da República (CF, art. 1ํ), embora elaborada em ambiente particular, exemplifica vulneração a dois direitos personalíssimos em prestígio à ordem pública: à (i) privacidade, desnudada, na qual, também, se colheu a (ii) própria imagem do agente.

Note-se que 0 art. 20 não endereçou proteção exclusiva à imagem. Cuidou, deslocada e impropriamente, da privacidade à qual dedicou, em local correto, o último artigo do Capítulo (CC, art. 21) ${ }^{87}$. Assegurar a ordinária inviolabilidade da "divulgação de escritos" é forma de tutela da privacidade. Textos ou anotações não revelam a imagem, mas pertencem à vida privada, sagrado e recôndito universo a que, somente o dono, pode permitir total ou parcial ingresso. Da própria imagem participam, ao revés, a "transmissão da palavra", porque da voz se trata, diverso componente evidenciador da imagem pessoal, também vulnerada com "a publicação, a exposição ou a utilização da imagem de uma pessoa", manifestação por excelência das formas plásticas ou físicas do titular do direito.

Nem só ou nem tanto por isso se apresenta atécnico o art. 20 do Código Civil. Se, sem aquiescência, a imagem divulgada — ou a privacidade vulnerada através da "divulgação de escritos", tal como ali formulada - não macular a honrar

87 O agrupamentos conceituais ou vocabulares em lei devem ter precisão insuperável, bem mais atenta em documentos nos quais se contenham regras fundamentais às relações civis comezinhas. "A lição a tirar", escreve Reed Dickerson (1965, p.82), "é que o redator deve tratar de um assunto, funcionalmente indivisível, num lugar só. Não deve fragmentá-lo. Nem deve enunciar a mesma regra em mais de um lugar". 
ou não revelar propósito de lucro, não haverá, de conformidade e para os fins da advertência final registrada no art. 20, tutela a uma ou outra: portanto, só haveria tutela do imagem à imagem "[...] se Ihe atingirem a honra, a boa fama ou a respeitabilidade, ou se se destinarem a fins comerciais" (CC, art. 20).

As condicionantes aí embutidas retiram a tutela da imagem e a depositam na honra. E quando assim não o é, o legislador confina a sanção à finalidade comercial da desautorização utilização. Vedou, aí, o enriquecimento ilícito, mas não obstou usurpação da imagem cuja tutela, a exemplo daquela que deferiu aos demais direitos personalíssimos, deveria postar acima das preocupações ou fruições de ordem material, porque materiais não são os bens que compõem a personalidade, motivo pelo qual a proteção a ela deferida haveria de contemplar a essência e não a consequência. Também porque o lucrum feito com a finalidade comercial extraída das potencialidades do direito violado nunca foi expressão segura ou aproximada do prejuízo pessoal experimentado pelo titular cujo direito foi desrespeitado. De tal sorte que a ofensa à honra ou a finalidade lucrativa da reprodução da imagem são únicas ocorrências que autorizam a tutela do jus imaginis na linguagem do Código Civil.

O Código Civil lusitano, de regramento exemplar aos direitos de 88 personalidade, a cada um dos quais, entre os arrolados, atribuiu título específico, fragmentou, em três alíneas, o Direito à imagem, que tratou no art. $79^{\circ}$ cuja redação é esta: "1. O retrato de uma pessoa não pode ser exposto, reproduzido ou lançado no comércio sem o consentimento dela; depois da morte da pessoa retratada, a autorização compete às pessoas designadas no no 2 do artigo 71, segundo a ordem nele indicada. 2. Não é necessário o consentimento da pessoa retratada quando assim o justifiquem a sua notoriedade, o cargo que desempenhe, exigências de polícia ou de justiça, finalidades científicas, didácticas ou culturais, ou quando a reprodução da imagem vier enquadrada na de lugares públicos, ou na de factos de interesse público ou que hajam decorrido publicamente. 3. O retrato não pode, porém, ser reproduzido, exposto ou lançado no comércio, se o facto resultar prejuízo

${ }^{88} \mathrm{~A}$ desinência que não agrega $\mathrm{o}$ artigo feminino à preposição de foi preferida por alguns escritores europeus, inclusive Otto Friedrich von Gierke (1895) e Andreas von Tuhr (1910, § 6ํ). Entre nós, Orlando Gomes a elegeu (1966, p. 5-10). 
para a honra, reputação ou simples decoro da pessoa retratada". A ressalva posta nesta última alínea endereça-se à exceção construída na alínea imediatamente anterior, até em tributo à técnica legislativa, que, se pretendesse destiná-la à primeira alínea, em seguida a ela própria tê-la-ia feito registrar ${ }^{89}$. A tutela à imagem é aí dotada de dimensão tal que perpassa o próprio interesse público se, a despeito da permissão ex vi legis (alínea $2^{2}$ ) para fazê-la divulgar quando dito e social interesse estiver presente, incorrer proibição, que, fundada na tutela incondicional da honra, se revelar apta a tornar indisponível a exposição da imagem, consoante prevalente doutrina ${ }^{90}$.

Imagem não é só o vultus, ou a reprodução plástica, física ou mecânica da pessoa. Além da representação das formas ou dos contornos, da silhueta ou do desenho, o fundamento do direito de imagem tem assento em qualquer manifestação ou representação identificável da pessoa (JABUR, 2003, p.16). A ensinança de Walter Moraes (1972) é suficiente: "Toda expressão formal e sensível da personalidade de um homem é imagem para o direito".

Imagem não se assemelha nem se confunde com honra ou privacidade. Com aquela não se mistura porque a honra concerne aos atributos pelos quais a pessoa é projetada aos olhos e às impressões de terceiros (reputação, que se afina com a honra objetiva) ou com aqueles característicos que nela infundem sentimento da própria honorabilidade (brio, que revela a honra subjetiva). Nada impede que a malferição da honra e da imagem resultem do mesmo ilícito. A privacidade compreende aspectos materiais e espirituais que jazem recônditos ao

${ }^{89}$ Assim comunga Rabindranath Valentino Aleixo Capelo de Sousa (1995, p.255): "a proibição do no 3 do art. $79^{\circ}$ do Código Civil, de divulgação do retrato se do facto resultar prejuízo para a honra, reputação ou simples decoro da pessoa retratada, tem de ser entendida em termos hábeis. Tal norma, pelo seu espírito e pela sua inserção sistemática (v.g., o emprego da adversativa $<<$ porém>>), parece valer directamente apenas para as hipóteses especiais do no 2 do art. $79^{\circ}$ do Código Civil, em que o retrato pode ser divulgado sem o consentimento da pessoa retratada por exigências de ordem social, e não também para o princípio geral do ํo 1 do mesmo artigo, em que se proíbe a divulgação de retrato sem o consentimento do retratado ou das pessoas que o substituem por sua morte"

90 Ou seja, "quando estes bens ["honra, reputação ou simples decoro"], pela sua elevada importância face à ponderação e avaliação dos interesses e valores jurídicos em causa, forem de considerar como indisponíveis, quando a limitação voluntária do seu exercício for contrária à ordem pública ou quando $o$ acto lesivo for contrário aos bons costumes [...], casos em que as ofensas consentidas à imagem devem ser consideradas como ilícitas" (Capelo de Sousa, 1995, mesma página). 
sabor de quem os titulariza. Não concernem à efígie nem a qualquer outra forma sensível de manifestação da pessoa, mas a elementos ou circunstâncias (fato) cuja revelação importa conhecer o que a pessoa tem (patrimônio, círculo de relacionamento, hábitos ou atitudes pessoais e sociais) ou faz (atividades e hobbies) e não ao que ou como a pessoa é (imagem: efígie, silhueta, voz, más ou boas características). Da honra se distancia, embora nela possa resvalar, tal a privacidade alcançar. $O$ achincalhe da honra é um majus à lesão pessoal quando o ofensor se serve da desconsentida utilização da imagem. A vexação da honra, mediante recurso à imagem, empiora e engrandece a lesão à personalidade, antes já usurpada pela desautorizada captação da imagem. De tal sorte que as ligações temerárias que se erguem entre imagem e quejandos assimila-se coerente a alguns prima facie, porém, vistas com minudência necessária, apresentam-se atécnicas e perturbadoras da particulares emanações da pessoa. Imagem, honra e privacidade podem sofrer conseqüente lesão. Se desnudo a privacidade de Tício, e dali retiro um retrato dele, usurpo-Ihe dois direitos distintos (privacidade e imagem). Mas se, demais disso, exibo ou divulgo dito retrato, que o evidencia em situação de constrangimento aos olhos comuns, alcanço-Ihe a honra, terceiro direito então maculado (JABUR, 2003, p. 20-21). ${ }^{91}$.

A tutela da captação da imagem, antecedente necessário ou não da divulgação pelo mesmo agente, não recebeu regramento no Código Civil. O desejo de não se revelar por intermédio de qualquer meio mecânico, eletrônico, digital ou informatizado que memorize a silhueta ou a texturização corporal, de não revelar a voz ou proibir, por qualquer uma dessas formas evolutivas, a reprodução gestual, bem ainda desautorizar a divulgação de características pessoais, boas ou más (imagem-atributo) ${ }^{92}$, concentra-se, em todas essas maneiras, na imagem, porque dela se irradiam. E essa irradiação só poderá ser ao mesmo tempo inaudita e lícita se o interesse público genuíno se apresentar, já porque e aí consultará à ordem

91 Sobre a autonomia do direito à própria imagem, as dessemelhanças entre esse direito, honra e privacidade, além da tutela de não se revelar nem pela captação nem pela divulgação desautorizadas, consultar p. 17-25 desse texto.

${ }_{92}$ No direito doméstico e em destaque, lê-se o conteúdo da imagem-atributo em Luiz Alberto David Araujo (1996, p. 31) e em Maria Helena Diniz (2004, p. 127). 
pública, já porquanto se revelará fundamental à "administração da justiça" (CC, art. 20) ${ }^{93}$. Assim, a antecedente captação da imagem, em local particular ou em local público cujo foco haveria de ser outro (o evento ou acontecimento), sem concordância do retratado, também recebe tutela. A correspondente divulgação é um plus potencializador do incômodo e da intranquilidade, do desassossego e do dissabor.

A ausência de proteção à captação da imagem, como também, para empiorar, o condicionamento da tutela à própria imagem à lesão da honra ou à obtenção de lucro através de sua exposição não se conciliam com a pura e claríssima salvaguarda cravada no art. 5ำ V e X, da Constituição Federal, que se omitiu em adjetivar para restringir. E fê-lo o constituinte cônscio do propósito de amplificar a tutela, não de cometer ao codificador civil, pela omissão constitucional, poder apto a restringir proteção dessa magnitude, magnânima porque implicada com a dignidade humana da qual se irradiam todos direitos personalíssimos, unidos ou não ${ }^{94}$.

De mais a mais, razão não se apura para distinguir a legitimidade genérica causa mortis do art. $12 \mathrm{com}$ a que se enxerga no art. 20. Naquela, também defeituosa pela ausência da atribuição legitimadora à pessoa companheira, a sucessão de vocacionados ao processo judicial contemplou, após o consorte, "qualquer parente em linha reta, ou colateral até o quarto grau". Na do art. 20, como se os preciosos direitos lá fixados fossem de valia menor - qual então sê-lo-ia de maior? -, a subsidiária faculdade de postular a proteção por lesão a direito antes titularizado pelo morto defere-se apenas para "o cônjuge, os ascendentes ou os descendentes".

\footnotetext{
${ }^{93}$ Logo, "se alguém tirar fotografia de outrem sem estar autorizado para isso, o retratado pode pedir a destruição do negativo e proibir a divulgação de seu retrato" (Maria Helena Diniz, 2002, p. 88).

${ }^{94} \mathrm{~A}$ independência e plenitude de conteúdo do direito à própria imagem, sem elo com o lucro ou a honra, já foram bem sedimentadas pelas Cortes de Superposição Federal (STJ, 4 ${ }^{\text {a }}$ Turma, REsp. 58.101-SP, Rel. César Asfor Rocha, j. 16.09.1997, DJU 09.03.1998, in RSTJ 104/326 e LEX-STJ 107/112) e Suprema (STF, 2 ${ }^{\mathrm{a}}$ Turma, RE 215.984, Min. Carlos Velloso, j. 04.06.2002, DJU 28.06.2002, p. 00143).
} 


\section{DIREITO À VIDA PRIVADA}

É lúcida a solução do legislador civil em não determinar o confinamento à vida privada (CC, art. 21). Redisse-se-a inviolável (CF, art. 5ํ, X) e ofereceu ao particular, novamente (CC, art. 12), o direito de impedir atentado ou fazê-lo cessar. Reatribuiu ao magistrado o poder de referendar os instrumentos jurídicos invocados para a tutela desse especial direito personalíssimo, quaisquer que se mostrem as "providências necessárias". É cláusula geral, como antes e aqui já afirmamos, que prestigia o dinamismo do sistema jurídico no qual a liberdade orientada do magistrado, de atuar conforme a judiciosidade criadora do pedido da parte, fornece ao ordenamento mais uma fonte jurídica, que se compreende nas plúrimas soluções acolhidas através dessa diretriz legal, que Ihe transfere a edificação do desate pelo adequado e estrito empuxo do postulante (CPC, arts. $2^{\circ}$ e $3^{\circ}$ ). Numa expressão, é do magistrado o controle da legalidade para "impedir ou fazer cessar ato contrário a esta norma" (CC, art. 21).

Como informam Paul Schwartz e Joel Reidenberg, o reconhecimento dos atributos do direito à vida privada apareceu, pela primeira vez, através do magistrado Thomas Cooley, em 1878 (Treatise on the law of torts). (SCHWARTZ; REIDENBERG, 1996, p.37).

Mas foi em 1890, por intermédio de Louis Brandeis, notável magistrado da Suprema Corte Americana, e Samuel Dennis Warren, próspero advogado estadunidense, que se edificou o right to be let alone (direito de ser deixado só) (BRANDEIS; WARREN, 1890, p.193-197).

Diversos e internacionais documentos renderam obséquio à privacidade, preservando-a de "ingerências arbitrárias" (DECLARAÇÃO UNIVERSAL DOS DIREITOS HUMANOS, 1948, art.12), nela decerto inclusos "domicílio" e "correspondências" 95-96.

\footnotetext{
95 Convenção para proteção dos Direitos Humanos e das Liberdades Fundamentais (Convenção Europeia de Direitos Humanos), 1950, art. 8‥

96 A Convenção Americana sobre Direitos Humanos (Pacto de São José da Costa Rica), 1969, reuniu o que num e noutro documento internacional se leu (art. 11,2).
} 
Rigorosa proteção ao âmbito da reserva se lê no art. 19 da Constituição da República Argentina, interessantemente conjugada com o princípio da legalidade: "As ações privadas dos homens que de nenhum modo ofendam à ordem pública, nem prejudiquem a um terceiro, estão apenas reservadas a Deus, e isentas da autoridade dos magistrados. Nenhum habitante da Nação será obrigado a fazer o que não manda a lei, nem privado do que ela não proíbe" ${ }^{97}$.

Em França, onde a construção protetiva aos direitos personalíssimos, bem fixada desde o início do séc. XX por trabalho da jurisprudência, o resguardo da vida privada foi disposto no art. 9o do Código Civil pela Lei no 70-643 de 17.07.1970 ${ }^{98}$.

A vida privada não pode ser apreendida, estandardizada. É infinita sua capacidade de manifestação. Não apresenta ela uma definição estática, mas de conformidade com as particulares e cambiantes características e com os variáveis costumes da pessoa ${ }^{99}$. A zona de resguardo ou reserva, que se altera pelo comportamento pessoal, subtrai da curiosidade e indiscrição alheias o que participa do círculo ou refúgio que a pessoa pretende tornar impenetrável. Querer ou não revelar aspectos próprios, que ao mundo pouco importam (apenas saciam a curiosidade sedenta ou alimentam os espíritos vis), é decisão que deve ser acolhida erga omnes. É faculdade de desnudar-se como e quando e em que circunstâncias queira o titular ${ }^{100}$.

Hoje se vê, em televisão, o franqueamento da privacidade para o espectador. Assim elaboram os reality shows a devassa da reserva pessoal mediante aquiescência. O consentimento para desnudar, conforme já se disse

\footnotetext{
${ }_{97}$ Através da Lei 21.173, de 22.10.1975, introduziu-se, para tutela da imagem e da privacidade, o art. 1.071 bis no Código Civil argentino (vigorante desde 1872, a partir da redação para um Código Civil brasileiro esboçada em 1860, em milhares de artigos, pela genialidade de Augusto Teixeira de Freitas).

98 "Art. $9^{\circ}$. Toda pessoa tem direito ao respeito da sua vida privada. Os juízes podem, sem prejuízo da reparação do dano experimentado, prescrever todas as medidas, tais como seqüestro, apreensão e outras, próprias a impedir ou fazer cessar um atentado à intimidade da vida privada; essas medidas podem, se houver urgência, ser ordenadas liminarmente."

99 É bem-posta a $2^{\mathrm{a}}$ alínea do art. $80^{\circ}$ do Código Civil português, assim redigida: "A extensão da reserva é definida conforme na natureza do caso e a condição das pessoas". A $1^{\circ}$ alínea tem essa redação: "Todos devem guardar reserva quanto à intimidade da vida privada de outrem".

100 Sobre a doutrinária distinção entre vida privada, intimidade e segredo, conquanto indiferente a proteção que a todos se colhe da lei, consultar: JABUR, 2000a, p. 255-7.
} 
antes, na ocasião em que se cuidou da limitação imposta pelo art. 11 do Código Civil, reveste-se de licitude se parcial e temporário o aproveitamento das virtudes econômicas do direito do qual se extrai o componente da comercialização ou simples divulgação. Quem desveste sua riservatezza e o faz cônscio a si molesta bem mais que à sociedade. John Stuart Mill escrevia, na metade do século antepassado, que "os atos de um indivíduo podem ser danosos a outro, ou faltar com a devida consideração ao bem-estar deste, sem irem ao ponto de violar algum dos seus direitos estabelecidos. Nesse caso, o ofensor pode ser justamente punido pela opinião, ainda que não pela lei" (MILL, 1942, p.136). A ofensa derivante da divulgação moderada da privacidade alheia, antes de colidir com aquilo que a sociedade tem por saudável entre seus hábitos (bons costumes) ou com os imperativos de disciplina por ela impostos e reclamados (ordem pública), malfere, e a responsabilidade por isso se desloca aos órgãos de comunicação social, os múltiplos e edificantes princípios fincados no art. 221 da Constituição Federal, sobretudo pelo desacato aos "valores éticos e sociais da pessoa da família" (inciso IV). Se ilicitude não se enxerga no consentimento do parcial e temporário franqueamento da ciência e exibição da privacidade pessoal (desde que, decerto, dela não se retire ato despudorado nem lascivo, que conduziria à ilicitude), é convinhável, por ocasião dela, mensurar e bem o peso (rectius, fardo) ético que o constituinte, lucidamente, depositou sobre os ombros dos comunicadores sociais. Se lícito é o contrato entre exibidor da intimidade e divulgador de massa, porque temporária a cessão econômica das potencialidades do direito personalíssimo, a exibição pública da reserva pessoal, nos moldes dos reality shows, se e quando reveladora de lubricidade, vulnera a dignidade humana, valor supremo, que dita e limita o alcance de todo e qualquer direito ou norma. A divulgação, ela sim, desmerece os costumes saudáveis, que, pela consulta à ética e à moral, se incorporaram e continuam incrustados no imo social ${ }^{101}$. Todavia, frise-se e frise-se bem, se a motivação do contrato, quer de uma quer de outra parte (CC, art. 112), for

${ }^{101}$ Assim escrevemos em (JABUR, 2004, p. 29). 
a exibição desmesurada e despudorada da privacidade pessoal, o contrato será irremediavelmente nulo por ilicitude de objeto (CC, art. 104, III).

A tutela da vida privada não se desvanece com a notoriedade ou fama. Diminui, mas sempre de conformidade com (i) interesse público inequívoco ${ }^{102}$, longe do qual ilícita será qualquer vulneração, e nos confins da (ii) necessidade da penetração da privacidade para a transmissão compreensível da notícia. Ajuntamse, para o devassamento da privacidade, a) o interesse público genuíno, b) a correlação entre a posição pública do protagonista e o dado de sua vida privada que se pretende revelar e $c$ ) o valor de atualidade da informação.

Tommaso Amedeo Auletta acrescenta que "é lícita somente a revelação das notícias privadas necessárias para um mais ponderado juízo sobre a atividade exercida pela pessoa mencionada", de tal sorte que somente "os episódios que têm uma íntima relação com a atividade que tornou o indivíduo notório, e não todas as outras", é que prestigiam a revelação da notícia (AULETTA, 1978, p.110-111).

Voga, pois, o princípio do desnudamento mínimo conforme o qual, e presente o público e inequívoco interesse, só é lícito o ingresso no raio da privacidade alheia que observar a menor violação dos dados ali encontrados se e quando conectados à atividade profissional ou pessoal que impele a quebra do recato.

O Código Civil negou tutela à privacidade da pessoa jurídica, o que não fez, com sobra de razões, o constituinte ( $\mathrm{CF}$, art. 5ํ, X). $\mathrm{O}$ art. 21 reconhece apenas a tutela à "pessoal natural". Os diversos argumentos alinhados em desfavor da extensão protetiva aos entes de direito, sem bem vistos, invalidam a irremovível necessidade de se manterem guardadas as insondáveis e infindáveis informações sem cuja proteção a sociedade não alcança seu propósito. Qualquer desempenho profissional, empresarial ou não, reclama planos e estratégicas, estudos e coleta incessantes de dados. Mesmo às sociedades filantrópicas ou benevolentes, cujo escopo estatutário desconhece o lucro, são elementares o emprego de

102 Sobre o conceito e alcance do inequívoco interesse público na atividade desempenhada pela imprensa, consultar: JABUR, 2000a, p. 286-95 (em virtude da notoriedade) e 336-56. 
planejamento, o estudo de conveniências, a captação e o manejo de associados (ou clientes), as técnicas de negociação (ou vendas), de distribuição de atividades e atribuições, estruturação de metas e implementação mercadológica.

Diversa fosse a recomendação do senso médio de percepção, inexistiriam tipificações expressivas em Código Penal endereçadas à divulgação de segredo (art. 153) e à violação de segredo profissional (art. 154), da violação ou sonegação de correspondência, comercial ou não, da comunicação telegráfica, radioelétrica ou telefônica (arts. 151 e 152), e do próprio domicílio (art. 150), também resguardados pela Constituição Federal (art. 5º, XI e XII). A Lei o 9.279/96 reúne proteção civil e penal de patentes, desenhos industriais e marcas, v.g.

A proteção do círculo concêntrico em que se apresenta a privacidade da pessoa jurídica ressoa há decênios. O Young Committee, criado em Londres, em 1969, alcançou um conceito satisfatório e comum de privacidade, pronunciou-se da seguinte forma: "Privacidade é o direito dos indivíduos, dos grupos ou instituições de determinar de que maneira e até que ponto as informações que os afetem podem ser comunicadas aos outros" (YOUNGER, 1972, §61).

De tal sorte que os elementos da privacidade da pessoa jurídica têm natural resguardo pelas suficientes razões que o fluxo das atividades e negócios da sociedade impõem. A privacidade do ente de direito é fundamental à tutela de sua própria existência. Despida do direito de conter e resguardar suas particulares informações e dados, de subtraí-los ao conhecimento indistinto, frustra-se a consecução do desiderato primacial para o qual é constituída qualquer sociedade.

O art. 52 do Código Civil, não apenas em obséquio ao direito à imagem, merece interpretação que fixe atentos olhos no art. $5^{\circ}, \mathrm{V}, \mathrm{X}, \mathrm{XI}$ e XII, da Constituição Federal, entre outras disposições nele desenvolvidas em prestígio da "pessoa".

\section{REFERÊNCIAS}

AQUINO, São Tomás de. Somme Théologique. Paris: Société Saint Jean l'Évangéliste, 1925. 
ARAUJO, Luiz Alberto David Araujo. A proteção constitucional da própria imagem. Belo Horizonte: Del Rey, 1996.

ASCENSÃO, José Oliveira. O Direito: Introdução e Teoria Geral. Lisboa: Fundação Caluste Gulbenkian, 1978.

AULETTA, Tommaso Amedeo. Riservatezza e tutela della personalità. Milano: Giuffrè, 1978.

BITTAR, Carlos Alberto. Os direitos da personalidade. Rio do Janeiro: Forense Universitária, 1995.

BRANDEIS, Louis e WARREN, Samuel Dennis. The right to privacy. In Harvard Law Review, v. 4, n. 5, 1890.

CARBONNIER, Jean Carbonnier. Droit civil - Les personnes. 20ed. Paris: PUF, 1996.

CARVALHO, Orlando de. Teoria geral do direito civil. Sumários desenvolvidos, em fascículos, Coimbra, 1981, p. 180

CHINELATO e ALMEIDA, Silmara Juny A. Direitos da personalidade do nascituro, Revista da Associação dos Advogados de São Paulo. São Paulo: AASP, 1992.

. Tutela Civil do Nascituro. São Paulo: Saraiva, 2000.

. Direito de Autor e Direito à Imagem. in Estudos de Direito do Autor, Direito da Personalidade, Direito do Consumidor e Danos Morais. Coord. Eduardo C. B. Bittar e Silmara Juny Chinelato. Rio de Janeiro: Forense Universitária, 2002.

CHIOVENDA, Giuseppe. Principios de derecho procesal civil. Madrid: Reus, 1922, t. 1.

CIFUENTES, Santos. Derechos personalísimos. 2ed. atual. e ampl. Buenos Aires: Astrea, 1995.

CORDEIRO, António Menezes. Os direitos da personalidade na civilística portuguesa, in Revista da Ordem dos Advogados, ano 61, Lisboa, 2001.

CRETELLA JÚNIOR, José. Curso de liberdades públicas. Rio de Janeiro: Forense, 1986. 
CUPIS, Adriano de. Os direitos da personalidade. trad. Adriano Vera Jardim e António Miguel Caeiro. Lisboa: Morais, 1961.

DANTAS, San Tiago. Programa de Direito Civil. Parte Geral. $2^{\underline{a}}$ tir. Rio de Janeiro: Editora Rio, 1979.

DECLARAÇÃO UNIVERSAL DOS DIREITOS HUMANOS. 1948. Palais de Chaillot, Paris.

DELEURY, Édith e GOUBOU, Dominique. Le droit des personnes physiques. 2ed. Québec: Ivon Blais, 1997.

DICKERSON, Reed. A arte de redigir leis. trad. Paulo de Castro Moreira da Silva. Rio de Janeiro: Forense, 1965.

DINIZ, Maria Helena Diniz. Curso de Direito Civil Brasileiro. 21ed., rev., aum. e atual. São Paulo: Saraiva, 2004, v. 1.

. Direto à imagem e sua tutela, in Estudos de Direito do Autor, Direito da Personalidade, Direito do Consumidor e Danos Morais. Coord. Eduardo C. B. Bittar e Silmara Juny Chinelato. Rio de Janeiro: Forense Universitária, 2002.

FERRARA, Francesco. Trattato de diritto civile italiano. Roma: Athenaeum, 1921, v. 1.

FRANÇA, Rubens Limongi. Direitos da personalidade - coordenadas fundamentais, in Revista do Advogado. São Paulo: AASP, 1992.

FRANÇA, Rubens Limongi. O nome civil das pessoas naturais (São Paulo, 1958).

GANGI, Calogero. Persone fisiche e persone giuridiche. Milano: Giuffrè, 1946.

GIERKE, Otto Friedrich von. Deutsches Privatrecht. Leipzig: Duncker \& Humblot, 1895, v. 1.

GOMES, Orlando. Direitos da personalidade, in Revista Forense, v. 216. Rio de Janeiro: Forense, 1966.

JABUR, Gilberto Haddad Jabur. Liberdade de pensamento e direito à vida privada - conflitos entre direitos da personalidade. São Paulo: RT, 2000a.

. O direito à não-cremação do cadáver humano e o valor dignidade, in Revista Atualidades Jurídicas, coord. Maria Helena Diniz. São Paulo: Saraiva, 2000b, v. 2. 
. Consentimento para devassa da privacidade nos reality shows, in Revista Jurídica Consulex. Brasília: Consulex, n. 169, janeiro de 2004.

. Limitações ao direito à própria imagem no novo Código Civil, in Questões Controvertidas no novo Código Civil. São Paulo: Método, 2003.

KAYSER, Pierre. Les droits de la personnalité: aspects théoriques et pratiques, in Revue Trimestrielle de Droit Civil. Paris: Sirey, 1971, ㄲo 3.

LEONARDI, Fernanda Stinchi Pascali. Voz e Direito Civil. São Paulo: Manole, 2013.

MARTINS, Ives Gandra da Silva. Os Direitos da Personalidade, in O novo Código Civil - Estudos em homenagem ao professor Miguel Reale, Coords. Domingos Franciulli Netto, Gilmar Ferreira Mendes e Ives Gandra da Silva Martins. São Paulo: LTr, 2003.

MAZEAUD, Henri, MAZEAUD, Léon, MAZEAUD, Jean e CHABAS, François. Leçons de droits civil. 8ed. Paris: Montchrestien, 1997, v. 2, t. 1.

MILL, John Stuart. Sobre a liberdade, trad. Alberto da Rocha Barros. São Paulo: Companhia Editorial Nacional, 1942.

MONTEIRO, Washington de Barros. Curso de Direito Civil. 39ed., rev. e atual. por Ana Cristina de Barros Monteiro França Pinto. São Paulo: Saraiva, 2003, v. 1.

MORAES, Walter. Direito à própria imagem. 1972. In: Revista dos Tribunais. V.443/65.

NIPPERDEY, Hans e SCHEFFER, Erna. Verhandlungen des Zweiundvierzigsten Deutscher Juristentag. Tübingen, Band II, 1959.

OLIVEIRA, José Lamartine Corrêa de e MUNIZ, Francisco Ferreira. O estado de direito e os direitos da personalidade, in RT 532/11. 1979.

PINTO, Paulo Mota. Direitos da Personalidade no Código Civil Português e no Novo Código Civil Brasileiro, in Revista Jurídica. Porte Alegre: Notadez, 2003, v. 314.

RIVERO, Jean. Libertés publiques. Paris: PUF, 1973, v. 1.

RODRIGUES, Silvio. Direito Civil. 34ed., atual. São Paulo: Saraiva, 2003, v. 1.

ROUBIER, Paul. Droits subjectifs et situations juridiques. Paris: Dalloz, 1963.

SCHWARTZ, Paulo e REIDENBERG, Joel. Data privacy law. Charlottesville: Michie, 1996. 
SOUSA, Rabindranath Valentino Aleixo Capelo de. Direito geral de personalidade. Coimbra: Coimbra Editora, 1995.

STA. MARIA, José Serpa de. Direitos da personalidade e sistemática civil geral. Campinas: Julex, 1987.

SZANIAWSKI, Elimar. Teoria geral dos direitos da personalidade. São Paulo: RT, 1993.

TEPEDINO, Gustavo. A tutela da personalidade no ordenamento civil-constitucional brasileiro, in Temas de direito civil. Rio de Janeiro, 1999, p. 36.

TOBEÑAS, José Castan Tobeñas. Los derechos de la personalidad, in Revista General de Legislacion y Jurisprudencia. Reus: Madrid, julho-agosto de 1952.

TUHR. Andreas von. Der Allgemeine Teil Des Deutschen Burgerlichen Rechts, Leipzig: Duncker \& Humblot, 1910, v. 1.

Andreas von. Derecho civil. Buenos Aires: Depalma, 1946, v. 1.

YOUNGER, Kenneth. Report of the committee on privacy. London: HMSO, 1972. 